\title{
Determining the \\ Kuvvet ve Hareket \\ misconceptions in the Force ünitesindeki kavram \\ and Motion unit with the yanilgilarinin çalişma \\ work sheets yapraklari ile belirlenmesi ${ }^{1}$
}

\author{
Handan Yerer ${ }^{2}$ \\ Fulya Öner Armağan ${ }^{3}$
}

\begin{abstract}
The aim of this study is to determine the misconceptions with the work sheets which are prepared for "Force and Motion" unit for 8th grade students. 12 worksheets, which were prepared by researchers in line with the learning outcomes of Force and Motion unit and relevant literature, were used in the research. Developed worksheets were delivered to 25 8th grade students for 3 weeks as the specified period in the curriculum. Content analysis method was employed in data analysis so as to determine misconceptions. As a result, the misconceptions of students about the concepts in Force and Motion unit were determined. "The quantity of liquid affects ascending force," "the ascending force affecting a floating object is greater than that object's weight" and similar misconceptions could be given as examples to the misconceptions included in the study findings. It is believed that this study will be a useful guide for teachers and researchers who aim for determining the misconceptions in force and motion subjects.
\end{abstract}

\section{Özet}

$\mathrm{Bu}$ çalışmanın amacı; 8. sınıf öğrencilerinin "Kuvvet ve Hareket" ünitesi için hazırlanan çalışma yaprakları ile kavram yanılgılarını belirlemektir. Araştırmada Kuvvet ve Hareket ünitesinin kazanımları ve ilgili alan yazın doğrultusunda araştırmacilar tarafindan hazırlanan 12 adet çalışma yaprağı kullanılmıştır. Geliştirilen çalışma yaprakları 25, 8. sınıf öğrencisine programda belirtilen süresinde 3 hafta boyunca uygulanmıştır. Verilerin analizinde kavram yanılgılarını belirlemek amacıyla içerik analizi tekniği kullanılmıştır. Sonuç olarak Kuvvet ve Hareket ünitesindeki kavramlarla ilgili öğrencilerdeki kavram yanılgıları belirlenmiştir. "Sıvı miktarı kaldırma kuvvetini etkiler." "Yüzen cisimlere etki eden kaldırma kuvveti, cismin ağırlığından büyüktür." gibi kavram yanılgıları, çalışma bulguları arasında yer alan yanılgilara örnek olarak gösterilebilir. $\mathrm{Bu}$ çalışmanın kuvvet ve hareket konularındaki kavram yanılg1larını belirlemeyi hedefleyen öğretmen ve araştırmacılara yol göstereceği düşünülmektedir.

\footnotetext{
${ }^{1}$ Bu çalışma ilk yazarın, Yrd. Doç. Dr., Fulya Öner Armağan danışmanlı̆̆ında hazırladı̆̆ Birimi SYL-2013-4908 kodlu yüksek lisans tezinin bir bölümünden üretilmiştir.

${ }^{2}$ Uzman, Fen Bilimleri Öğretmeni, handanyerer@hotmail.com

${ }^{3}$ Yrd. Doç. Dr., Erciyes Üniversitesi, Eğitim Fakültesi, onerf@erciyes.edu.tr
} 
Yerer, H., \& Öner Armağan, F. (2015). Kuvvet ve Hareket ünitesindeki kavram yanılgılarının çalışma yaprakları ile belirlenmesi. International Journal of Human Sciences, 12(2), 858-880. doi:10.14687/ijhs.v12i2.3391

Keywords: Misconceptions, worksheet, force Anahtar Sözcükler: Kavram yanılgısı, çalışma and motion yaprağ1, kuvvet ve hareket

(Extended English abstract is at the end of this document)

\section{Giriş}

Fen olayları, insanların yaşamlarında önemli bir yere sahiptir. Feni anlamak ancak doğru bir fen eğitimi sayesinde olur. Bu durumda, fen eğitiminin kalitesi oldukça büyük bir öneme sahiptir. Ülkemizde bugüne değin fenin geleneksel yöntemlerle öğretimi sebebiyle fen başarı oranının düşük olduğu tespit edilmiştir (Eğitimi Araştırma Geliştirme Dairesi Başkanlığı, [EARGED], 2003). Öğretim programlarında da bu sorunu gidermek için öğrencilerin anlamlı öğrenmesine yardımcı olan alternatif öğretim yaklaşımlanına ağırlı verilmektedir. Bu yaklaşımlardan biri de öğrencilerin yaparak-yaşayarak öğrenmesini ilke edinen yapılandırmacı yaklaşımdir.

Yapılandırmacı yaklaşımda öğrenciler bilgiyi bireysel olarak yapılandırır, bilgileri aynen kullanmazlar. Öğrenmede bireyin ön bilgileri, kişisel özellikleri ve öğrenme ortamı son derece önemli bir yere sahiptir (Smith, Disessa, \& Roschelle, 1993). Öğrencilerin ön bilgileri, onların öğrenmelerini olumlu ya da olumsuz yönde etkileyen faktörlerlerden biridir (Pines \& West 1986; Pintrich, Marx, \& Boyle, 1993). Bu nedenle öğrencilerin ön bilgilerini tespit etmek (Beeth, 1998) ve ayrıca bu doğrultuda bir eğitim vermek oldukça önemlidir (Engel Clough, \& Driver, 1986; Hewson \& Hewson, 1988). Çünkü öğrenciler fen öğrenimleri sırasında, yeni gelen bilgiyi, var olan fikir ve inaçları ile yorumlar ve bu doğrultuda da yeni bilgiler değiştirilir ya da yeniden yapilandirilır (Palmer, 1999).

Zihinde doğru olarak yapılandırılamayan kavramlar, kavram yanılgilarına neden olmaktadır. Kavram yanılgısı bilimsel olarak doğru kabul edilen bilgilerle uyumsuzluk gösteren düşüncelerdir (Clement, Brown, \& Zietsman, 1989). Kavram yanılgıları, kullanılan yöntem ve tekniklerin eksikliğinden kaynaklanabilir. Geleneksel öğretim yöntemlerinin kavram yanılgılarını gidermede yetersiz kalabildiği birçok çalışmada vurgulanmaktadır (Dykstra, Boyle, \& Monarch, 1992; Pines \& West, 1986).

Doğru şekilde kullanılan öğretim yöntem ve teknikleri, eğitimin kalitesini olumlu yönde etkilemektedir. Öğrencilerdeki mevcut kavram yanılgılarını iyi belirlemek, ilerde oluşabilecek hataların önüne geçebilir. Kavram yanılgılarını belirlemede kullanılan yöntemlerden biri de açık uçlu soru ve etkinliklerin yer aldığı çalışma yapraklarıdır. Çalışma yaprakları kullanılma kolaylığı, içeriğe uygun hazırlanabilme avantaj1 ve dersi monotonluktan kurtarma yönü ile fen eğitiminde tercih edilen alternatif öğretim yöntemlerinden biridir (Demirel, 2001). Alan yazında da çalışma yaprakları ile kavram yanılgılarının belirlenmesi yoluna gidilmiş ve bu çalışma sonuçlarına göre de çalışma yapraklarının kavram yanılgılarını belirlemede etkili olduğu sonucuna varılmıştır (Atasoy \& Akdeniz, 2006; Atasoy, 2008; Chong, Salleh, \& AiCheong, 2013; Şahin, İpek Akbulut, \& Çepni, 2012; Ünal \& Coştu, 2005).

Öğrencilerin önceki deneyimleri ile ilişkileri ve bu deneyimler sonucunda kurdukları zihinsel bağlantılar, kavram yanılgıları hakkında bilgi veren unsurlardır. Kavram yanılgıları, yeni bilginin öğrenilmesi için engel oluşturmaktadır (Novak, 2002). Bu nedenle yapılandırmacı 

belirlenmesi. International Journal of Human Sciences, 12(2), 858-880. doi:10.14687/ijhs.v12i2.3391

yaklaşımda, öğrencinin ön bilgilerinin ne olduğuna hâkim olmak, öğretmenler için oldukça önemlidir (Gil-Perez \& Carrascosa, 1990). Çünkü ön bilgilerin yetersiz ya da yanlış olması durumunda, gerekli müdahaleyi yapabilmek, ünitenin sağlıklı bir şekilde öğretilmesi adına oldukça önemlidir. Yukarıda kısaca bahsedilen kavram yanılgılarının oluşma sebepleri ile birlikte, mevcut kavram yanılgılarının düzeltilebilmesi için, bu yanılgıların neler olduğunun belirlenmesi de oldukça önemlidir. Bu noktada çalışma yaprakları ile alınan bilgiler, kavram yanılgılarını belirleyip düzeltmede, öğretim sürecine katkı sağlayacaktır. Bu nedenle, bu çalışmada çalışma yapraklarının sekizinci sınıf Kuvvet ve Hareket ünitesi için hazırlanması ve uygulanması amaçlanmıştır.

Fen programinda sarmal olarak ilerleyen konulardan biri de "Kuvvet ve Hareket" ünitesidir (MEB, 2013). Bu nedenle bu ünite fiziğin temel konularından biridir. Günlük hayatta karşımıza çıkan bir fen olayının temelindeki sebebi anlamak yerine, onu olduğu gibi kabul etmek; sorgulama yeteneğimizi körelten bir durumdur. Örneğin "kaldırma kuvveti”, "basınç" ve "yoğunluk" gibi kavramlar hayatımız boyunca hep karşılaş̧ı̆ıımız fakat sorgulama ihtiyacı duymadığımız kavramlardır. "Kaldırma kuvveti”, "yüzme”, "batma" ve "basınç" gibi kavramların verildiği, hangi olayın neden kaynaklandığını açılayan bu ünite; yapılandırmacı yaklaşıma dayalı çalışma yaprakları ile daha kolay ve kalıcı halde anlatılabilir. Ayrıca, çalışma yapraklarına verilecek cevaplar doğrultusunda, mevcut kavram yanılgıları da tespit edilebilir.

"Kuvvet ve Hareket" ünitesinin basınç ve kaldırma kuvveti konularının, yapısında soyut kavramlar barındırdığ 1 için öğrenciler tarafindan anlaşılmasının zor olduğu ve bu konularda öğrencilerin çeşitli kavram yanılgılarına sahip oldukları çeşitli araştırmalarda tespit edilmiştir (Besson, 2004; Besson \& Viennot, 2004; Bozan \& Küçüközer 2007; Önen, 2005; Şahin, 2010; Ünal \& Coştu, 2005; Yelgün, 2009). Bu durum yapılandırmacı yaklaşıma dayalı yöntem ve tekniklerle düzeltilebilir. Araştırma boyunca kullanılan çalışma yaprakları da bu amaca hizmet etmek için hazırlanmıştır. Öğrencilerin fikirlerini kendi ifadeleri ile dile getirmeleri, çalışma yapraklarını kullanma sebebinin başında gelmektedir. Öğretmenler, çalışma yaprakları hazırlayarak ders anlattıklarında, öğrencilere bu firsatı sunmuş olurlar.

\section{Yöntem}

\section{1. Çalışma Deseni}

$\mathrm{Bu}$ araştırmada nicel araştırma yöntemlerinden tarama yöntemi kullanılmıştır. Tarama yöntemi var olan kayıt ve belgeleri inceleyerek veri toplamaktır (Karasar, 2005).

\section{2. Çalışma Grubu}

Araştırmanın çalışma grubu, 2013-2014 eğitim-öğretim yılı birinci yarıyılında Türkiye'nin Kayseri ilinde bulunan sosyoekonomik düzeyi iyi bir ortaokulda öğrenim gören 8. sinıf öğrencileri olarak belirlenmiştir. Çalışmaya 25 sekizinci sınıf öğrencisi katılmıştır. Bu öğrenciler rastgele olarak seçilemediğinden uygun örnekleme tekniğiyle seçilmiştir. Bu gruptaki öğrenciler 14-15 yaş aralığındadır. 15 öğrenci kız, 10 öğrenci ise erkektir.

\subsection{Veri Toplama Arac1}

Sekizinci sınıf Kuvvet ve Hareket ünitesi ile ilgili kavram yanılgılarını belirlemek için oluşturulan çalışma yaprakları, 12 adet olup, tamamı araştırmacılar tarafından hazırlanmıştır. Bu 
Yerer, H., \& Öner Armağan, F. (2015). Kuvvet ve Hareket ünitesindeki kavram yanılgılarının çalışma yaprakları ile belirlenmesi. International Journal of Human Sciences, 12(2), 858-880. doi:10.14687/ijhs.v12i2.3391

yapraklar hazırlanırken son beş yılın merkezi sınavlara hazırlık test kitaplarının ünite kazanımlarına hitap eden konuları ve Milli Ĕ̆itim Bakanlı̆̆ı'nın ders kitapları incelenmiştir. Ayrıca alan yazındaki ilgili çalışmalar da incelenerek öğrencilerin zorlandıkları konular ele alınmıştır. Daha sonra bu yapraklar, iki fen öğretmeni ve bir fen eğitimcisi tarafindan incelenmiş ve gerekli düzenlemeler yapılmıştır. Hangi kazanımın hangi çalışma yaprağını temsil ettiği aşağıdaki tabloda görülmektedir;

Tablo 1.

Calışma Yapraklarının Kazanımlara Göre Dă̆ılımı

\begin{tabular}{ll}
\hline KAZANIMLAR & Çalışma Yaprakları \\
\hline 1.1. Bir cismin havadaki ve sıvı içindeki a ğırlı̆̆ını dinamometre ile ölçer ve ölçümlerini & \\
kaydeder & Havada Mi Ağır, \\
1.2. Cismin havadaki ve sıvı içindeki ağırlıklarını karılaştırır & Sıvıda Mı? \\
1.3. Cismin sıvı içindeki ağırlığının az görüldüğü sonucunu çıkarır &
\end{tabular}

1.4. Sıvı içindeki cisme, sıvı tarafından yukarı yönde bir kuvvet uygulandığını fark eder ve bu kuvveti kaldırma kuvveti olarak tanımlar

1.5. Kaldırma kuvvetinin cisme aşağ yönden etki eden kuvvetin etkisini azalttı̆̆ sonucuna

Ben Bilirim varir.

1.6. Bir cisme etki eden kaldırma kuvvetinin büyüklüğünün cismin batan kısmının hacmi ile ilişkisini araştırır.

1.7. Cisimlerin kütlelerini ve hacmini ölçerek yoğunluklarını hesaplar. $\quad$ Eşleştirme Oyunu 1

1.8. Bir cisme etki eden kaldırma kuvvetinin büyüklüğünün, cismin daldırıldığı sıvının Ben Bilirim yoğunluğu ile ilişkisini araştırır.

1.9. Farklı yoğunluğa sahip sıvıların cisimlere uyguladığı kaldırma kuvvetini karşılaştırır ve Batarsa Batar, sonuçları yorumlar. 1.10. Bir cismin yoğunluğu ile daldırıldığ sıvının yoğunluğunu karşılaştırarak yüzme ve
batma olayları için bir genellirme Oyunu 1

1.11 Denge durumunda, yüzen bir cisme etki eden kaldırma kuvvetinin cismin ağırlığına eşit olduğunu fark eder.

1.12. Batan bir cisme etki eden kaldırma kuvvetinin, cismin a ğırlı̆̆ından daha küçük olduğunu fark eder.

Kim A $\breve{g ̆}_{11}, \quad$ Kim Hafif?

Ya Taşarsa!

1.13. Bir cisme etki eden kaldırma kuvvetinin, cismin yer değiştirdiği sıvının ağırlı̆̆ına eşit büyüklükte ve yukarı yönde olduğunu keşfeder.

Tabloları Dolduralım

1.14. Gazların da cisimlere bir kaldırma kuvveti uyguladığını keşfeder.

1.15. Sıvıların ve gazların kaldırma kuvvetinin teknolojideki kullanımına örnekler verir ve Gazların Kuvveti bunların günlük hayattaki önemini belirtir.

2.1. Birim yüzeye etki eden dik kuvveti, basınç olarak ifade eder.

2.2. Basınç, kuvvet ve yüzey alanı arasındaki ilişkiyi örneklerle açıklar.

Eşleştirme Oyunu 2

2.3. Sıvıların ve gazların basıncının bağlı olduğu faktörleri ifade eder.

2.4. Basınca sebep olan kuvvetin çeşitli etkenlerden kaynaklanabileceğini fark eder. $\quad$ Deney Yapalım mı?

2.5. Sıvıların ve gazların basıncı her yönde aynı büyüklükte ilettiğini keşfeder

Balon ve Yay

2.6. Sıvıların ve gazların, basıncı iletme özelliklerinin teknolojideki kullanım alanlarını araştırır.

2.7. Basıncın, günlük hayattaki önemini açıllar ve teknolojideki uygulamalarına örnekler

Basınç ve Biz verir.

Kavram yanılgılarının belirlenmesi, çalışma yapraklarının "Sorgulama ve Değiştirme" ile "Uyarlama” bölümlerine verilen cevaplardan çıkartılmıştır. Bu bölümler için verilen cevaplarda, öğrencilerin önceki bilgileri sorgulanmakta, yeni bilgilerle uyumu hakkında bilgi toplanmaktadır. 

belirlenmesi. International Journal of Human Sciences, 12(2), 858-880. doi:10.14687/ijhs.v12i2.3391

\subsection{Uygulama Şekli}

Tüm konular hafta hafta fen programına uygun olarak işlenmiş ve toplamda 12 adet olan çalışma yaprakları, dersin son 15 dakikasında dağıtılmıştır. Her derste o günkü dersin kazanımları doğrultusunda, o kazanımları temsil eden çalışma yaprakları öğrencilere dăğtılmış, uygulama esnasında da sınıfın fen öğretmeni sınıfta bekleyerek, gelen soruları cevaplamıştır. Çalışma yaprakları her öğrenci tarafindan bireysel olarak yapılmıştır. Öğrencilerin daha rahat davranması, sorularını daha rahat sorması ve yabancı birinin sinıfta bulunmasının öğrencileri rahatsız edebileceği fikrinden yola çıkarak, yapılan tüm uygulamaları sınıfın fen öğretmeni yapmış, araştırmacılar derste gruba katılmamıştır.

\subsection{Verilerin Analizi}

Verilerin analizinde nicel araştırma yöntemlerinden tarama yönteminin iki alt bölümünden biri olan içerik analizi tekniği kullanılmıştır. İçerik analizi, bir belgenin, belli özelliklerini sayısallaştırarak belirleme amacıyla yapılan bir taramadır. Belgelerdeki belli bakış açıları, felsefeler, dil anlatım vb özellikler, derinliğine ve belli ölçütlere göre yapılacak çözümlemelerle anlaşılabilir (Karasar, 2005).

Çalışmada her ders sonunda o günkü kazanıma hitap eden çalışma yaprakları sınıf genelinde uygulanmış, elde edilen veriler araştırmacılar tarafindan ayrı ayrı incelenerek, kavram yanılgıları sayısallaştıılıışıtır. Her iki araştırmacı tarafından tespit edilen kavram yanılgıları ele alınarak bunlar üzerinde fikir birliği sağlanarak araştırmanın güvenirliği arttırılmaya çalışılmıştır (Miles \& Huberman, 1994).

Çalışma yapraklarında içerik analizi yapılırken kavram yanılgısına sahip öğrenci sayısını belirlemede belirli bir sınırlamaya gidilmemiştir. Örneklem sayısının az olması sebebiyle, bir ögrencinin yaptığ kavram yanılgısı bile dikkate alınmıştır.

\section{Bulgular}

Araştırmanın birinci çalışma yaprağı "Havada mı A ğır, Sıvı da mı?” başlıklı bir materyaldir (Şekil 1). Bu çalışma yaprağı ile fen ve teknoloji dersi sekizinci sınıf programındaki "Kuvvet ve Hareket" ünitesinin sıvıların ve gazların kaldırma kuvveti ile ilgili ilk üç kazanımı hakkında öğrencilerdeki kavram yanılgıları ( KY) tespit edilmeye çalışılmıştır. Burada tespit edilen kavram yanılgıları aşağıda verilmiştir. Bu yanılgıların yanında yazan sayılar, kaç öğrencinin bu yanılgı̀a sahip olduğunu göstermektedir;

1. KY=Swn miktarn arttıksca, cisme uygulanan kaldırma kuvveti artar (3).

2. $K Y=$ Swu miketar değ iştikese kaldurma kuvveti de değ işir (2).

3. $K Y=$ Sw miktar de

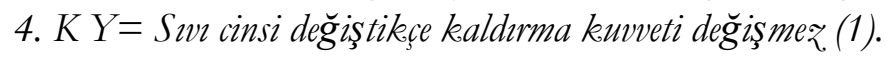

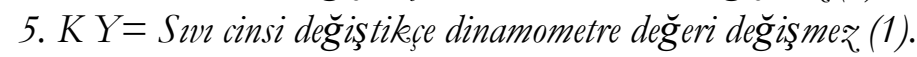


Yerer, H., \& Öner Armağan, F. (2015). Kuvvet ve Hareket ünitesindeki kavram yanılgılarının çalışma yaprakları ile belirlenmesi. International Journal of Human Sciences, 12(2), 858-880. doi:10.14687/ijhs.v12i2.3391

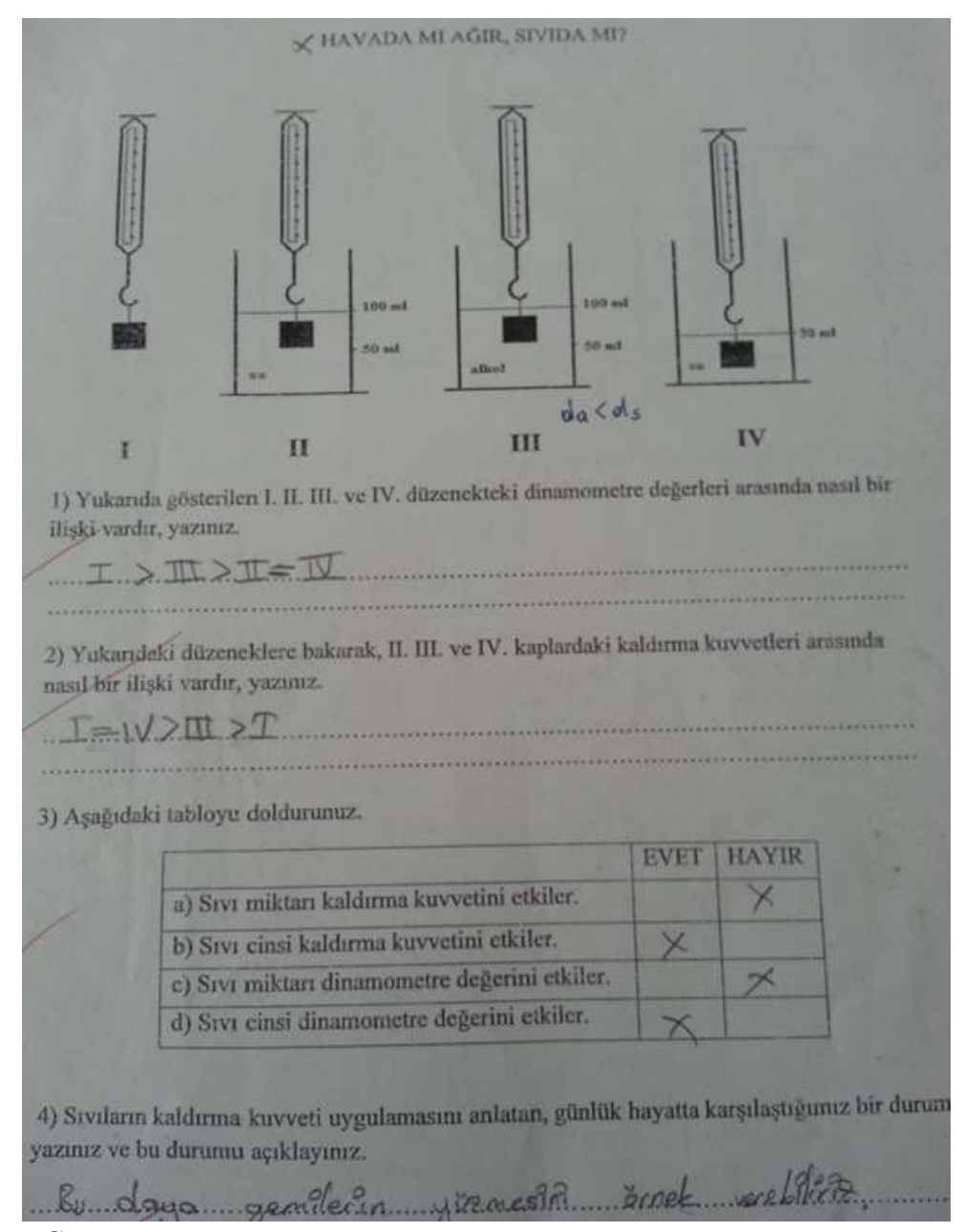

Şekil 1.Birinci çalışma yaprağına örnek

Araştırmanın ikinci çalışma yaprağ "Ben Bilirim" başlıklı bir materyaldir (Şekil 2). Bu çalışma yaprağı ile fen ve teknoloji dersi sekizinci sınıf programındaki "Kuvvet ve Hareket" ünitesinin sıvıların ve gazların kaldırma kuvveti ile ilgili dördüncü, beşinci, sekizinci ve dokuzuncu kazanımları hakkında öğrencilerdeki kavram yanılgıları tespit edilmeye çalışılmıştır. Bu çalışma yaprağında sadece bir öğrencinin kavram yanılgisına düştüğü tespit edilmiştir. Burada tespit edilen kavram yanılgısı şu şekildedir;

6. K Y= Yoğunluk azaldıkça, gerilme kuvveti de az̧alir (1). 
Yerer, H., \& Öner Armağan, F. (2015). Kuvvet ve Hareket ünitesindeki kavram yanılgılarının çalışma yaprakları ile belirlenmesi. International Journal of Human Sciences, 12(2), 858-880. doi:10.14687/ijhs.v12i2.3391

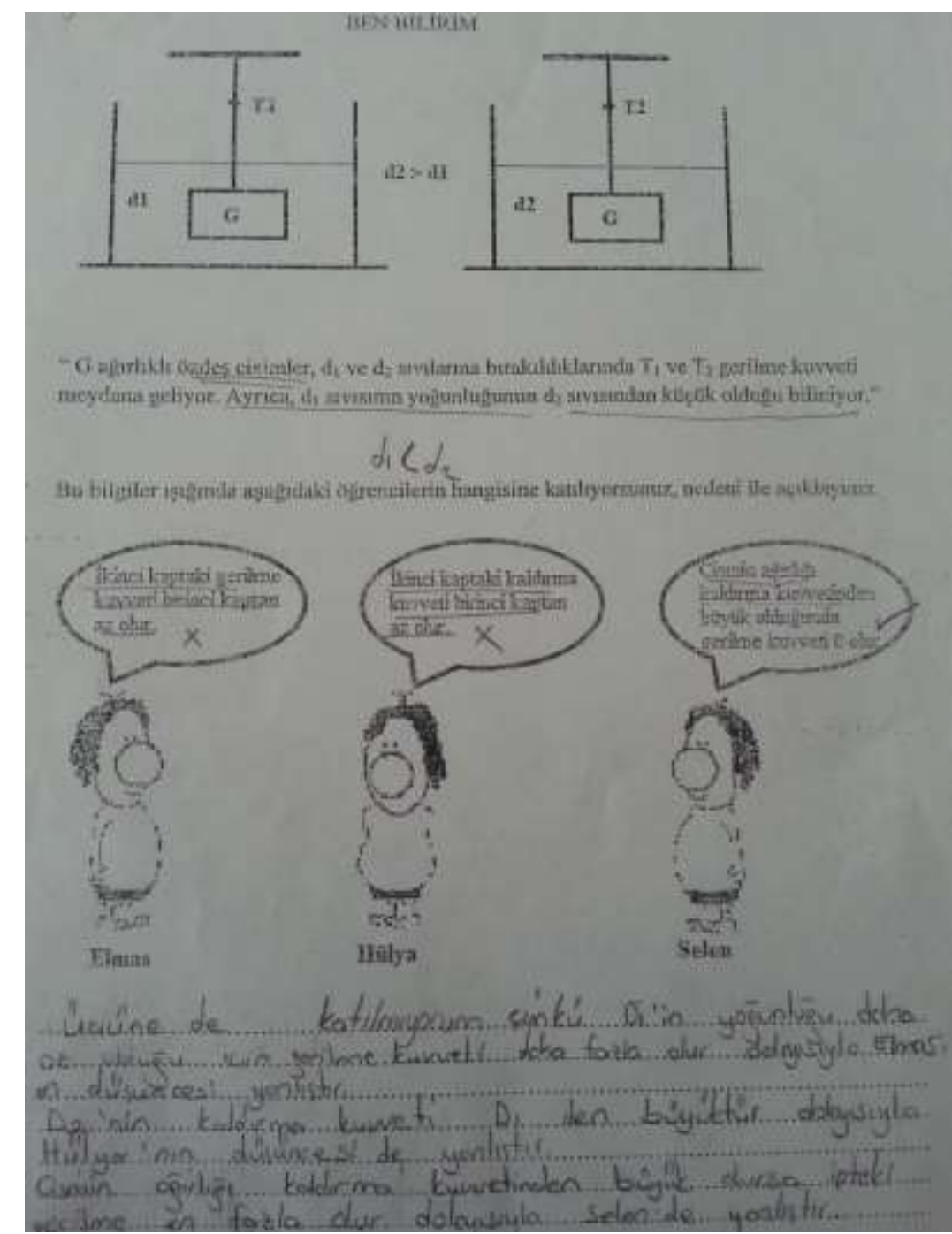

Şekil 2.İkinci çalışma yaprağına örnek;

Araştırmanın üçüncü çalışma yaprağı "Ya Taşarsa!” başlıklı bir materyaldir (Şekil 3). Bu çalışma yaprağı ile fen ve teknoloji dersi sekizinci sınıf programındaki "Kuvvet ve Hareket" ünitesinin sıvıların ve gazların kaldırma kuvveti ile ilgili altıncı kazanımı hakkında öğrencilerdeki kavram yanılgıları tespit edilmeye çalışılmıştır. Burada tespit edilen kavram yanılgıları aşağı da verilmiştir;

7. $K Y=$ Yüren cisimler hacimlerinden daha büyük hacimde sun taşırur (1).

8. $K Y=$ Askeıda kalan cisimler hacimlerinden daha kü̈ü̈ hacimde sivn taşurur (1).

9. $K Y=$ Batan cisimler hacimlerinden daba büyüle bacimde siv taşırn (2).

10. $K Y=$ Askeıda kalan cisimlerin yoğunluğu, suvmmkinden büyüktür (1).

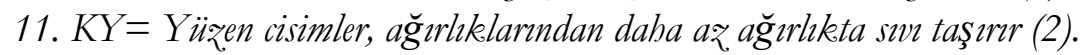

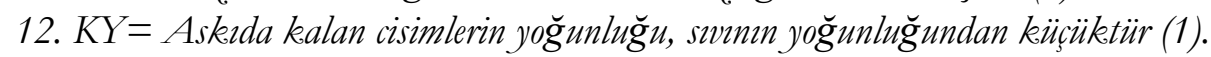

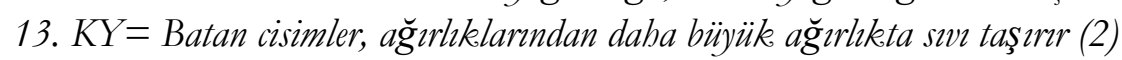

14. $K Y=$ Yüzen cisimlerin hacmi, taşan sivmm hacmi ile aynudır (3).

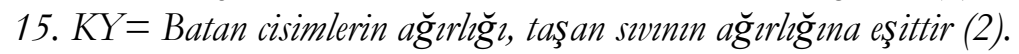

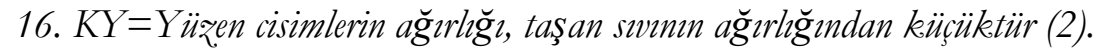


Yerer, H., \& Öner Armağan, F. (2015). Kuvvet ve Hareket ünitesindeki kavram yanılgılarının çalışma yaprakları ile belirlenmesi. International Journal of Human Sciences, 12(2), 858-880. doi:10.14687/ijhs.v12i2.3391

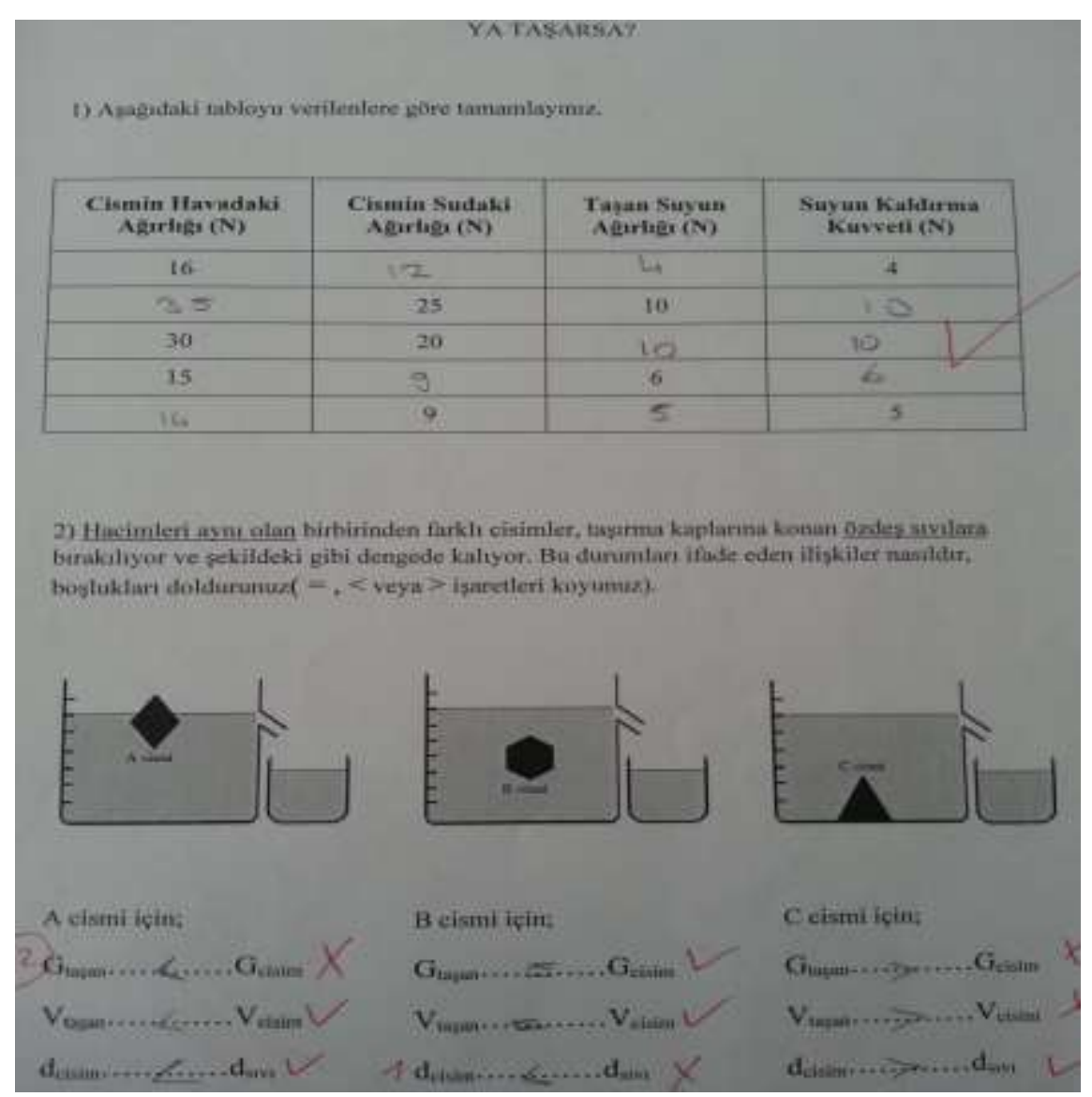

Şekil 3.Üçüncü çalışma yaprağına örnek

Araştırmanın dördüncü çalışma yaprağı "Eşleştirme Oyunu 1" başlıklı bir materyaldir (Şekil 4). Bu çalışma yaprağ ile fen ve teknoloji dersi sekizinci sınıf programındaki "Kuvvet ve Hareket" ünitesinin sıvıların ve gazların kaldırma kuvveti ile ilgili yedinci ve onuncu kazanımları hakkında öğrencilerdeki kavram yanılgıları tespit edilmeye çalışılmıştır. Bu çalışma yaprağında yoğunluğu bilinen bir cismin, yoğunluğu bilinen bir sıvı içerisindeki yüzme ve batma durumu 5 kişi tarafından ilişkilendirilememiş fakat bunlardan sadece 1 kişi çizim yapabilmiş diğer 4 kişi ise çizim kısmını boş bırakmıştır. Yanlış çizim yapan kişide tespit edilen kavram yanılgısı şu şekildedir;

17. $K Y=$ a) yoğunluğu sivn ile aym olan cisimler sivida batar.

b) yoğunluğu sividan büyü̈k olan cisimler sivida askıda kalır. 
Yerer, H., \& Öner Armağan, F. (2015). Kuvvet ve Hareket ünitesindeki kavram yanılgılarının çalışma yaprakları ile belirlenmesi. International Journal of Human Sciences, 12(2), 858-880. doi:10.14687/ijhs.v12i2.3391

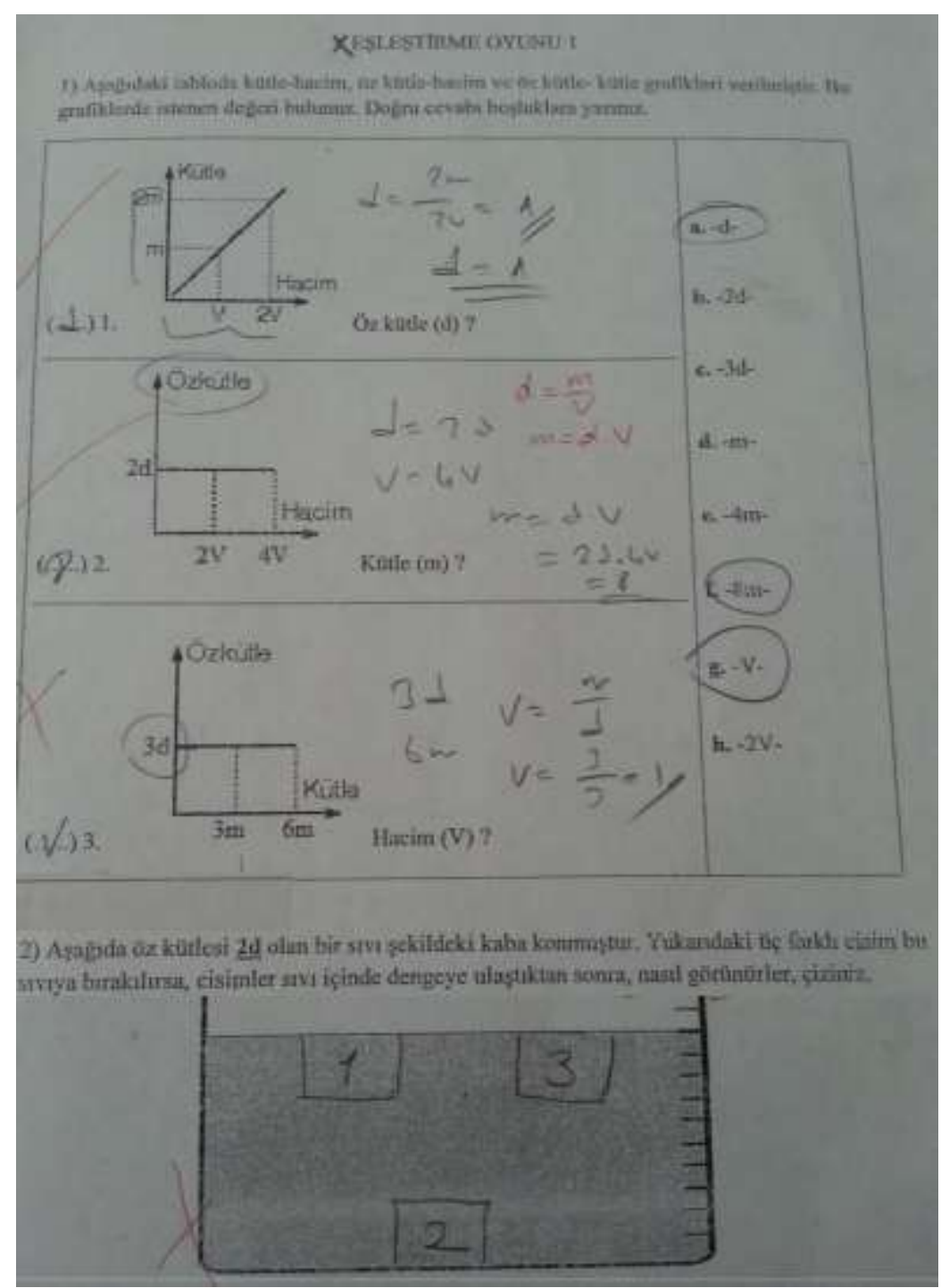

Şekil 4.Dördüncü çalışma yaprağına örnek

Araştırmanın beşinci çalışma yaprağı "Batarsa Batar, Çıłarsa Çıkar" başlıklı bir materyaldir (Şekil 5). Bu çalışma yaprağı ile fen ve teknoloji dersi sekizinci sınıf programındaki "Kuvvet ve Hareket" ünitesinin siviların ve gazların kaldırma kuvveti ile ilgili sekizinci ve dokuzuncu kazanımları hakkında öğrencilerdeki kavram yanılgıları tespit edilmeye çalışılmıştır. Burada tespit edilen kavram yanılgıları aşă̆g da verilmiştir;

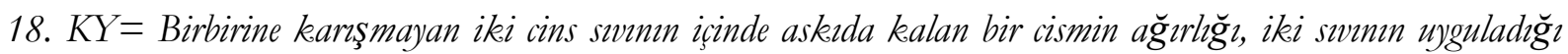
kaldrrma kuvvetinin toplamina eşit değildir (10).

19. $K Y=$ Kabın hacmi, cismin swn içindeki konumunu etkiler.

a) Sivr kabun genişletmek, cismi aşăg $ı$ indirir (2).

b) Siv kabın daraltmak, cismi yukar çıkarır (2).

c) Sivn kabin genişletmek, cismi yukar çıkarır (3).

d) Sivı kabın daraltmak, cismi aşağı indirir (3).

20. $K Y=$ Sw miktar, cismin sivn içindeki konumunu etkiler.

a) Sivı miktarm arttrmak, cismi yukarı çıarır (2).

b) Sun miktarm azaltmak, cismi aşăg $ı$ indirir (1).

21. KY= Swr yoğunluğunu azaltmak, askıda kalan bir cismin konumunu değ iștirmez. (2) 
Yerer, H., \& Öner Armağan, F. (2015). Kuvvet ve Hareket ünitesindeki kavram yanılgılarının çalışma yaprakları ile belirlenmesi. International Journal of Human Sciences, 12(2), 858-880. doi:10.14687/ijhs.v12i2.3391

22. $K Y=$ Sivr yoğunluğunu arttrmak, askıda kalan bir cismin konumunu değiştirmez. (3).

23. $K Y=$ Cismin yoğunluğu svinn yoğunluğundan kü̧̈ükse, cisim batar (2).

24. $K Y=$ Birbirine karışmayan iki cins swmmn içinde askeıda kalan bir cisme, iki sum aym anda kaldurma kuvveti uygulamaz. (4).

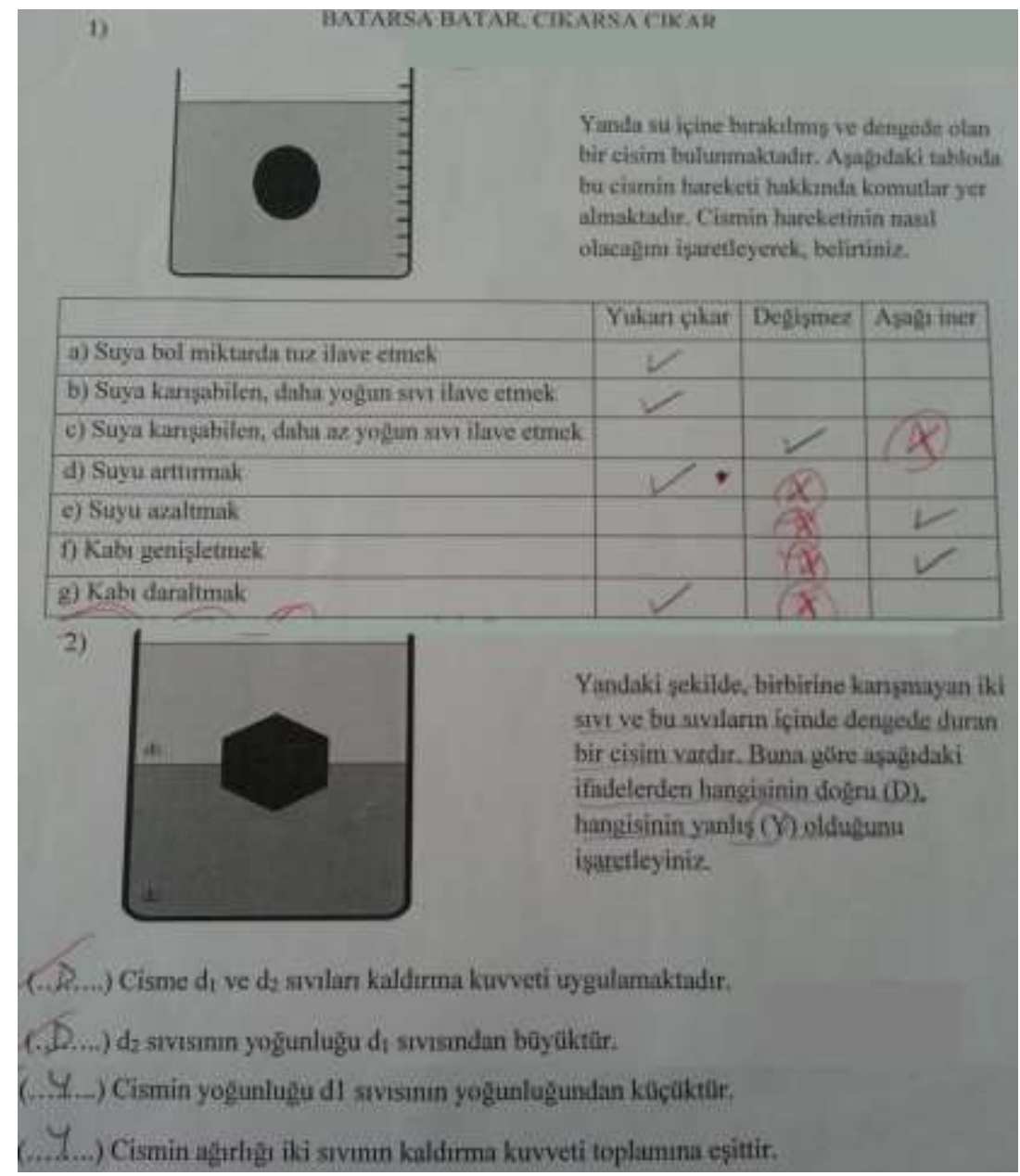

Şekil 5.Beşinci çalışma yaprağından örnek

Araştırmanın altıncı çalışma yaprağ “'Kim A ̆̆ır, Kim Hafif?” başlıklı bir materyaldir (Şekil 6). Bu çalışma yaprağı ile fen ve teknoloji dersi sekizinci sınıf programındaki "Kuvvet ve Hareket" ünitesinin sıvıların ve gazların kaldırma kuvveti ile ilgili on birinci ve on ikinci kazanımları hakkında öğrencilerdeki kavram yanılgıları tespit edilmeye çalışılmıştır. Burada tespit edilen kavram yanılgıları aşağıda verilmiştir;

25. $K Y=$ Yüzen cisimlere etki eden kaldırma kuvveti, cismin ă̆ırlı̆gndan büyüktür, (5).

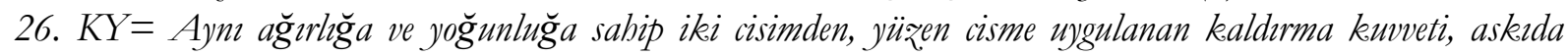
kalandan daba farladir (3).

27. $K Y=$ Özdeş swnlar içindeki eşit hacimli fakat farkh yoğunluklu cisimlerden, yüzen cisim ile askıda kalan cisme eşit kaldırma kuvveti uygulanır (7)

28. $K Y=\ddot{O}$ zdeş sunlar içindeki eşit hacimli fakat farkh yoğunluklu cisimlerden, askeıda kalan cisme, batan cisimden daha fazla kaldirma kuvveti uygulanır (3)

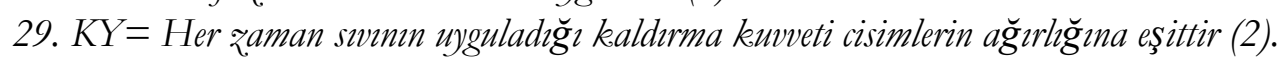

30. $K Y=$ Askıda kalan cisimlerin kabu ăgıllaştırma miktar, batan cisimlerden fazladır (9) 
Yerer, H., \& Öner Armağan, F. (2015). Kuvvet ve Hareket ünitesindeki kavram yanılgılarının çalışma yaprakları ile belirlenmesi. International Journal of Human Sciences, 12(2), 858-880. doi:10.14687/ijhs.v12i2.3391

31. $K Y=$ Askida kalan cisimler ile batan cisimlerin kabu ăgırlaştırma miktarlarn eşittir (5)

32. $K Y=$ Özdeş cisimler, kendilerinden daba az yoğunluktaki sunlarda dengede kalır (yüzer ya da askıda kalir), daba çok yoğunluklu sivilarda ise dibe batar (3).

33. $K Y=$ Dengede olan (yüzen ya da askıda kalan) cisimlere batan cisimlerin kabu ağırlaştırma miktarlar eşittir. (5).

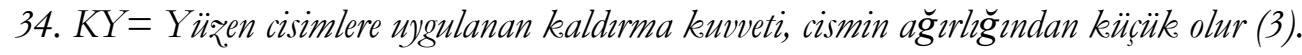

35. $K Y=$ Batan cisimlere uygulanan kaldırma kuvveti, cismin a $\breve{g}$ irlğ̈ından büy ük olur (2)

36. $K Y=$ Yüzme ile askıda kalma arasinda, cisimlerin yoğunluklar bakımmndan bir fark yoktur (1)

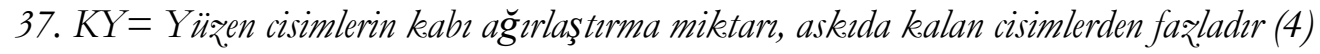

38. $K Y=$ Yüzen cisimlerin kabr ăgılastırma miktar, askıda kalan cisimlerden azder (3)

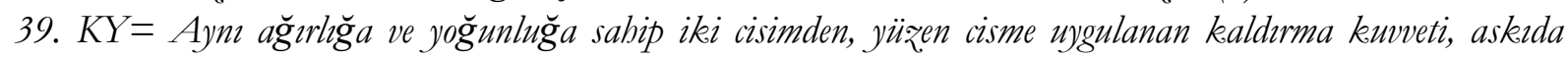
kalandan daba azder (1).

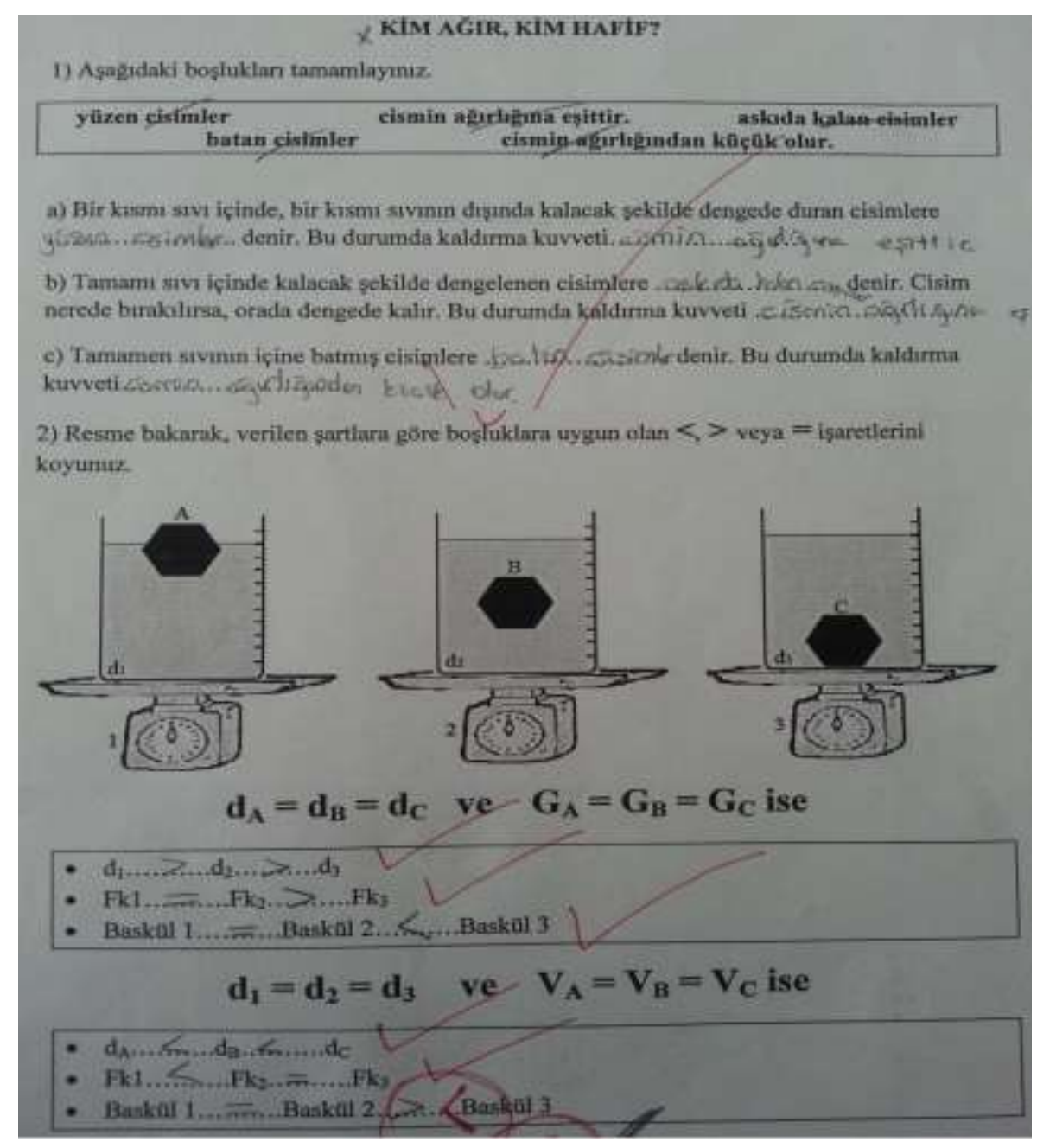

Şekil 6. Altıncı çalışma yaprağına örnek

Araştırmanın yedinci çalışma yaprağ ${ }_{1}$ "Tabloları Dolduralım” başlıklı bir materyaldir (Şekil 7). Bu çalışma yaprağı ile fen ve teknoloji dersi sekizinci sınıf programındaki "Kuvvet ve Hareket" ünitesinin sıvıların ve gazların kaldırma kuvveti ile ilgili on üçüncü kazanımı hakkında öğrencilerdeki kavram yanılgıları tespit edilmeye çalışılmıştır. Burada tespit edilen kavram yanılgıları aşağıda verilmiştir; 
Yerer, H., \& Öner Armağan, F. (2015). Kuvvet ve Hareket ünitesindeki kavram yanılgılarının çalışma yaprakları ile belirlenmesi. International Journal of Human Sciences, 12(2), 858-880. doi:10.14687/ijhs.v12i2.3391

40. $K Y=$ Yer değiştiren suvmm hacmi ile eşit bölmelere aynlmuş cismin bacmi hesaplanamiyor (3).

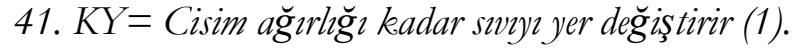

42. $K Y=A \breve{g}$ irllk birimi olarak $\mathrm{cm}^{3}$ kullanilyor (1).

43. KY= Sivmm son hacmi, yer değģştiren sivmm hacmi demektir (2).

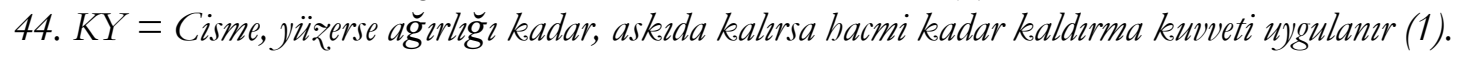

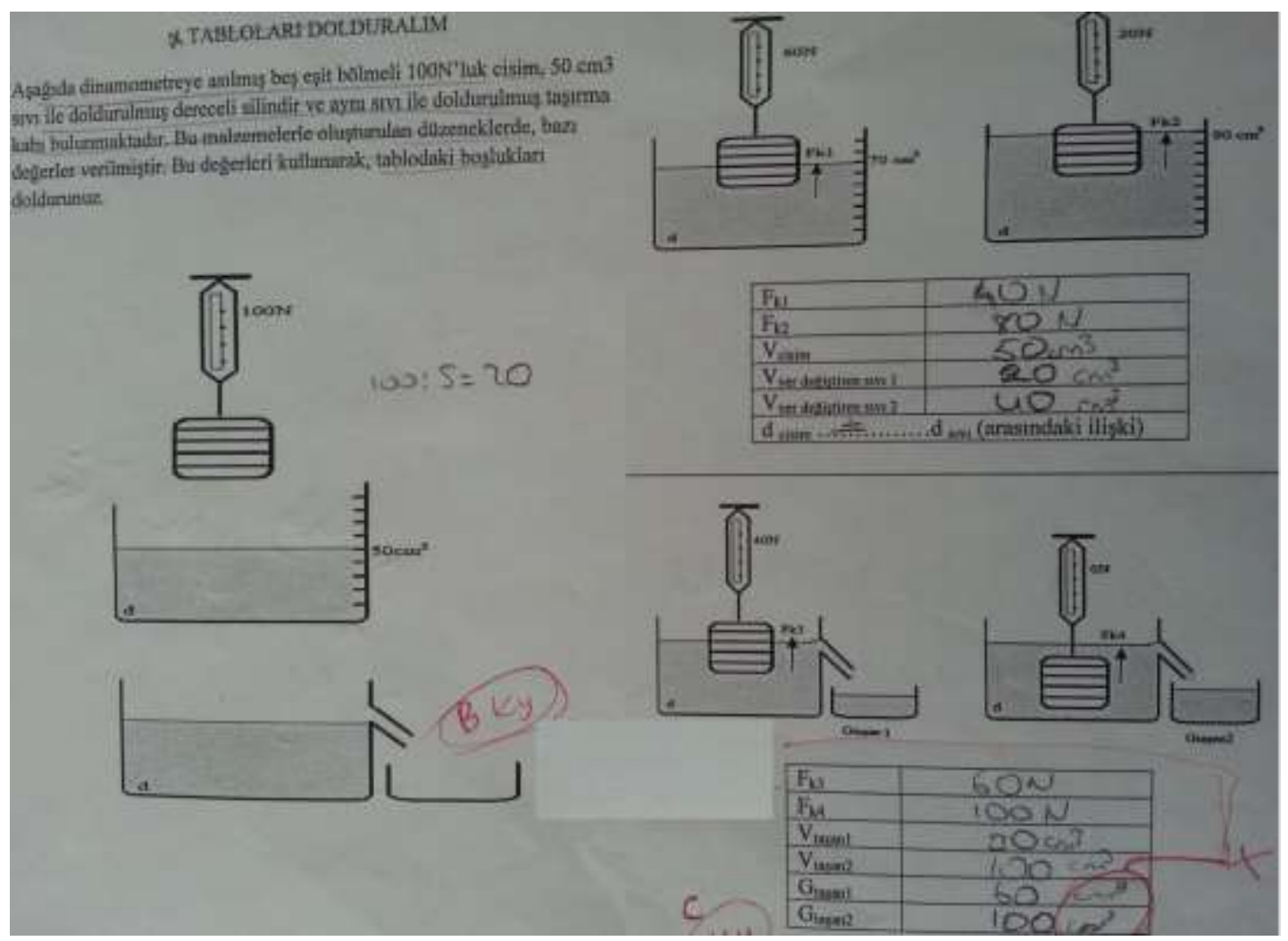

Şekil 7.Yedinci çalışma yaprağına örnek

Araştırmanın sekizinci çalışma yaprağı "Gazların Kuvveti” başlıklı bir materyaldir (Şekil 8). Bu çalışma yaprağı ile fen ve teknoloji dersi sekizinci sınıf programındaki "Kuvvet ve Hareket" ünitesinin sıvıların ve gazların kaldırma kuvveti ile ilgili on dördüncü ve on beşinci kazanımları hakkında öğrencilerdeki kavram yanılgıları tespit edilmeye çalışılmıştır. Burada tespit edilen kavram yanılgıları aşağıda verilmiştir;

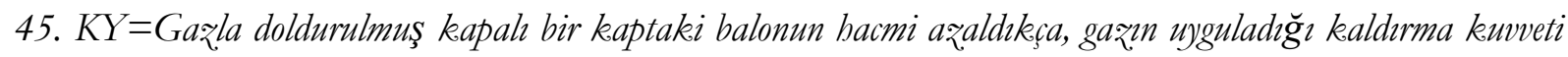
artar ve balon yukarn çıar (15).

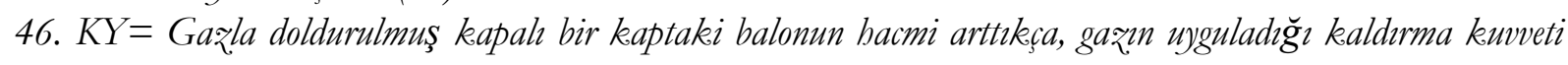
azalir ve balon aşăg iner (13).

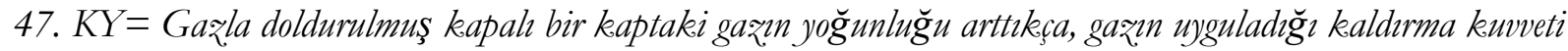
azalir ve balon aşăg $\breve{g}_{l}$ iner (5).

48. KY= Gąla doldurulmuş kapah bir kaptaki gazın yoğunluğu azaldıkça, gazın uyguladĭg kaldırma kuvveti artar ve balon yukarı çıar (7).

49. $K Y=$ Gąlarm basinct, cismin cinsine bă̆hdır (1).

50. KY= Gazlarn kaldirma kuvveti, cismin ă̆ 
Yerer, H., \& Öner Armağan, F. (2015). Kuvvet ve Hareket ünitesindeki kavram yanılgılarının çalışma yaprakları ile belirlenmesi. International Journal of Human Sciences, 12(2), 858-880. doi:10.14687/ijhs.v12i2.3391

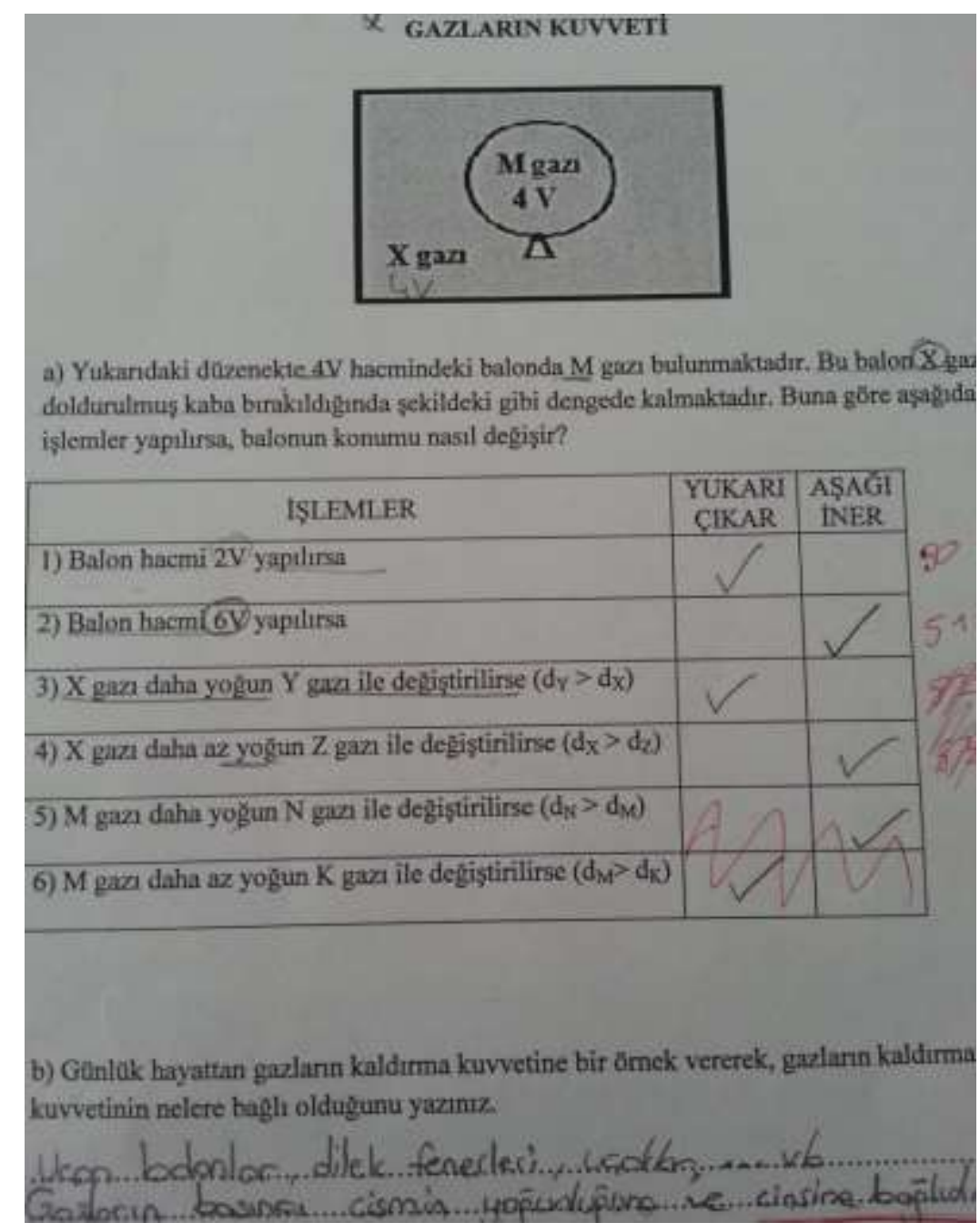

Şekil 8.Sekizinci çalışma yaprağına örnek

Araştırmanın dokuzuncu çalışma yaprağı "Eşleştirme Oyunu 2" başlıklı bir materyaldir (Şekil 9). Bu çalışma yaprağı ile fen ve teknoloji dersi sekizinci sınıf programındaki "Kuvvet ve Hareket" ünitesinin basınç ile ilgili birinci, ikinci ve üçüncü kazanımları hakkında öğrencilerdeki kavram yanılgıları tespit edilmeye çalışılmıştır. Burada tespit edilen kavram yanılgıları aşağıda verilmiştir;

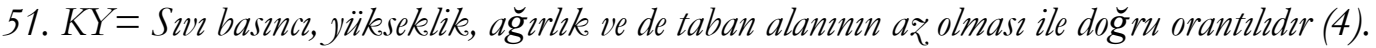

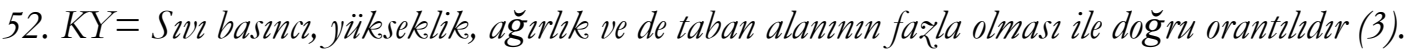

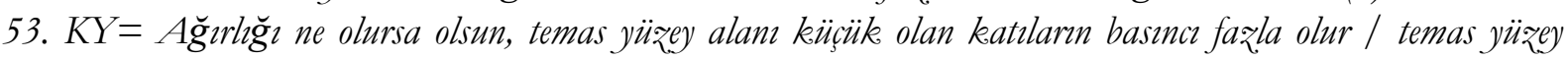
alam büyü̈k olan katılarm basinc kü̧̈̈̈k olur (10).

54. $K Y=$ Temas yüzey alam büyü̈e olan katılarm basinc fazla olur (1).

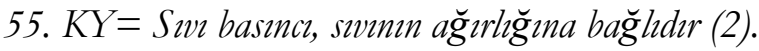

56. $K Y=$ Yüksekliğ $i$ ne olursa olsun, temas yüzey alanı kü̈ü̈k olan kaplarn sivn basinc faそla olur / temas yürey alanlar büyük olan kaplarn sivi basince az olur (10).

57. $K Y=$ Sivr basinc, sivr bacmine băghdor (1). 
Yerer, H., \& Öner Armağan, F. (2015). Kuvvet ve Hareket ünitesindeki kavram yanılgılarının çalışma yaprakları ile belirlenmesi. International Journal of Human Sciences, 12(2), 858-880. doi:10.14687/ijhs.v12i2.3391

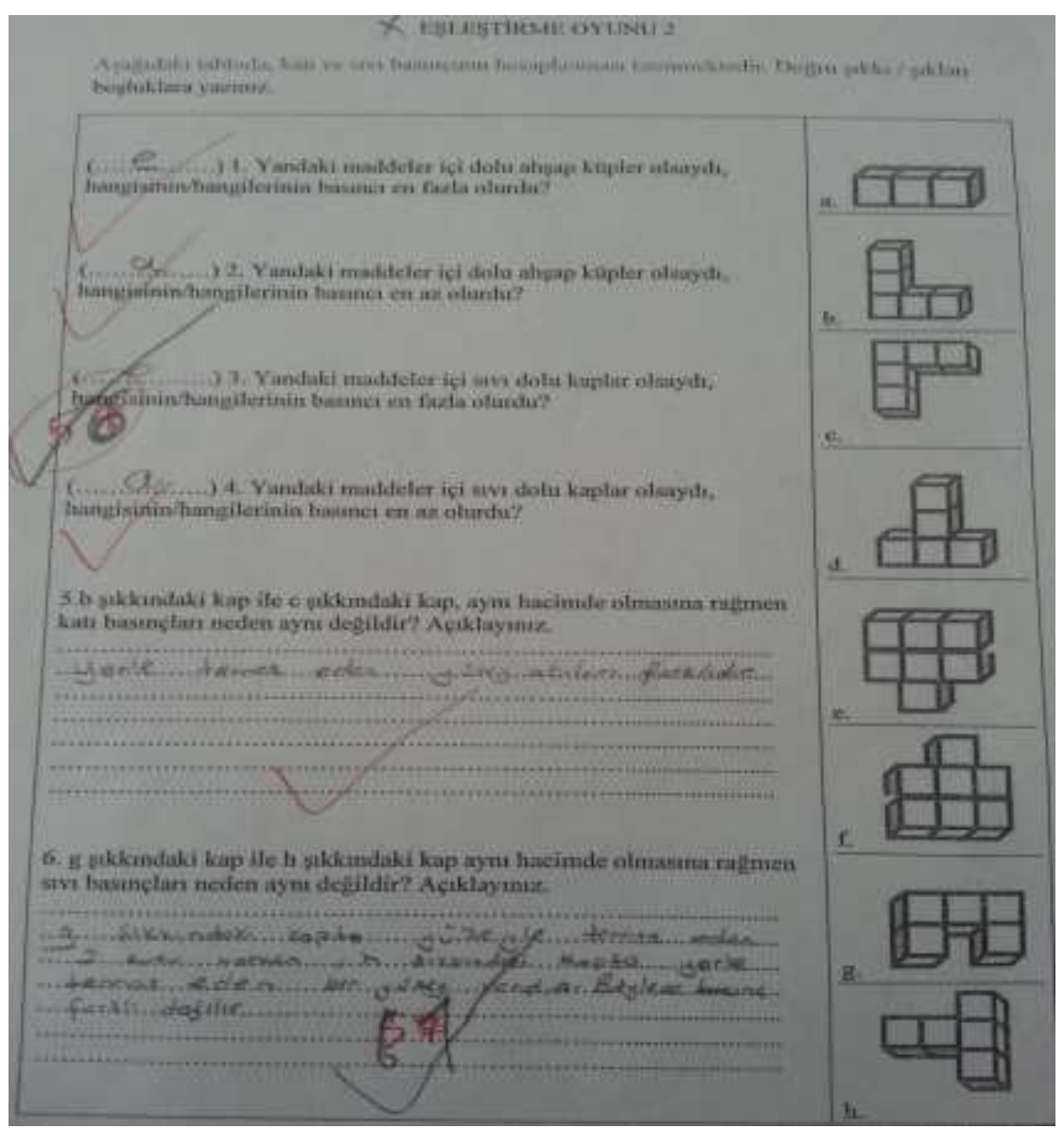

Şekil 9.Dokuzuncu çalışma yaprăğına örnek

Araştırmanın onuncu çalışma yaprağı "Deney Yapalım Mı?” başlıklı bir materyaldir (Şekil 10). Bu çalışma yaprağ 1 ile fen ve teknoloji dersi sekizinci sınıf programındaki "Kuvvet ve Hareket" ünitesinin basınç ile ilgili dördüncü kazanımı hakkında öğrencilerdeki kavram yanılgıları tespit edilmeye çalışılmıştır. Burada tespit edilen kavram yanılgıları aşağıda verilmiştir;

58. KY= Sw basinc kabin şekline băghdir (11).

59. $K Y=$ Siv basinci yüleseklik ile ters orantilidir (4).

60. $K Y=S w$ basincm bem yükeseklike hem de kesit alanı etkiler (1).

61. KY=Sivi basincı kabin kesit alani ile ters orantilidir (1). 
Yerer, H., \& Öner Armağan, F. (2015). Kuvvet ve Hareket ünitesindeki kavram yanılgılarının çalışma yaprakları ile belirlenmesi. International Journal of Human Sciences, 12(2), 858-880. doi:10.14687/ijhs.v12i2.3391

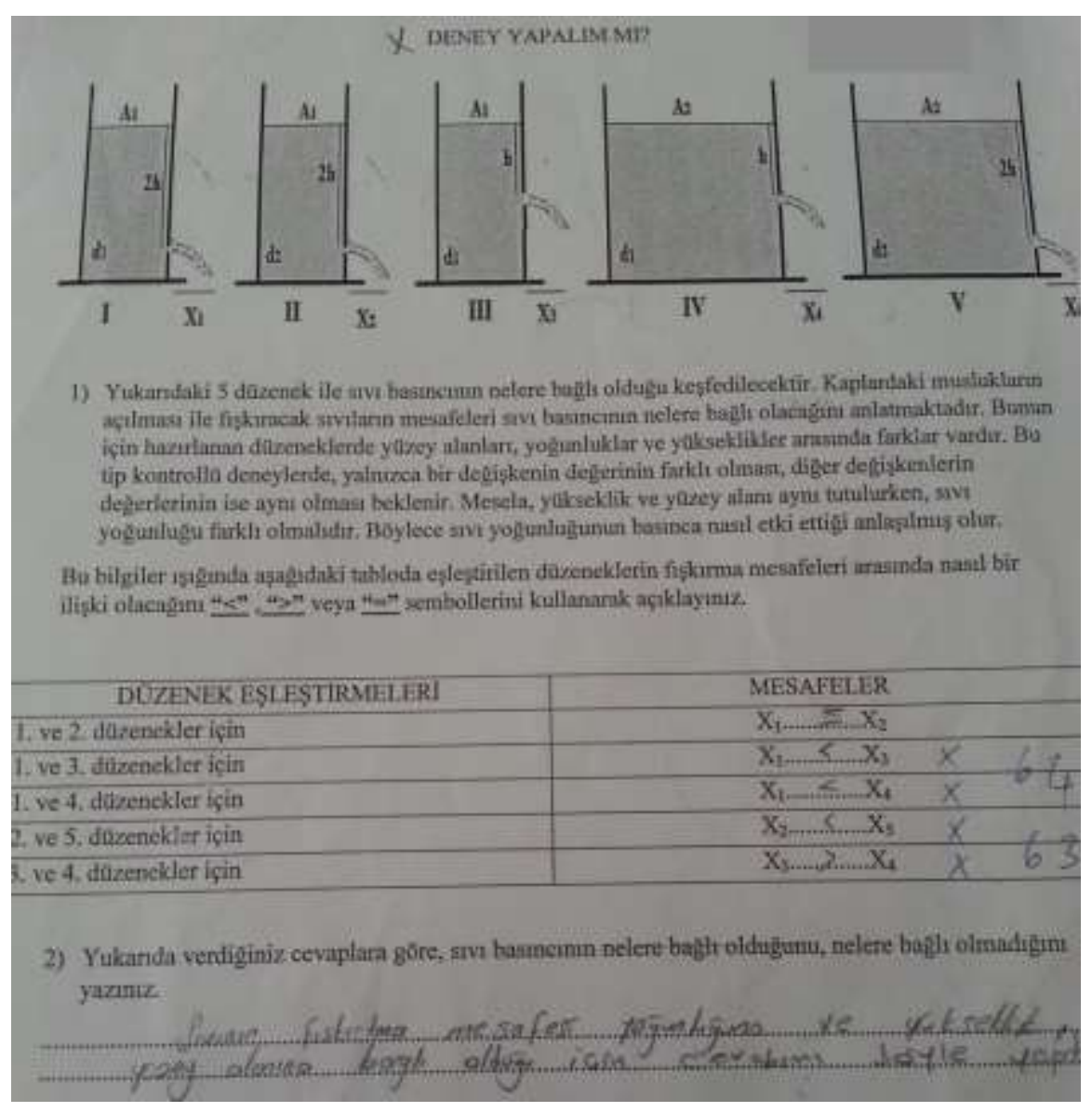

Şekil 10.Onuncu çalışma yaprağına örnek

Araştırmanın on birinci çalışma yaprağ "Balon ve Yay" başlıklı bir materyaldir (Şekil 11). Bu çalışma yaprağı ile fen ve teknoloji dersi sekizinci sınıf programındaki "Kuvvet ve Hareket" ünitesinin basınç ile ilgili beşinci kazanımı hakkında öğrencilerdeki kavram yanılgıları tespit edilmeye çalışılmıştır. Burada tespit edilen kavram yanılgıları aşağıda verilmiştir;

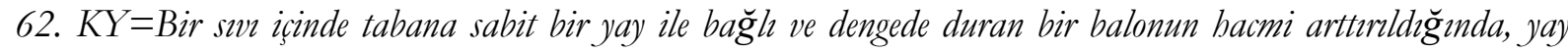
gerilmesi azalir (14).

63. KY= Bir sivn içinde tabana sabit bir yay ile bă̆l ve dengede duran bir balonun bacmi az̧altıldı̆̆ında, yay gerilmesi artar (17).

64. KY=Bir sivn içinde tabana sabit bir yay ile bă̆g ve dengede duran bir balon dürenenğinde, swn yoğunluğunun artması balona uygulanan basinc değiştirmez. (4).

65. KY= Bir sivn içinde tabana sabit bir yay ile bă̆l ve dengede duran bir balon düzenĕginde, sivn miktar balona uygulanan basıncı değgistirmez. (3).

66. $K Y=$ Bir sivn içinde tabana sabit bir yay ile băgh ve dengede duran bir balon düzenĕginde, swn yoğ unluğunun artmasi yay gerilmesini artturr (1). 
Yerer, H., \& Öner Armağan, F. (2015). Kuvvet ve Hareket ünitesindeki kavram yanılgılarının çalışma yaprakları ile belirlenmesi. International Journal of Human Sciences, 12(2), 858-880. doi:10.14687/ijhs.v12i2.3391

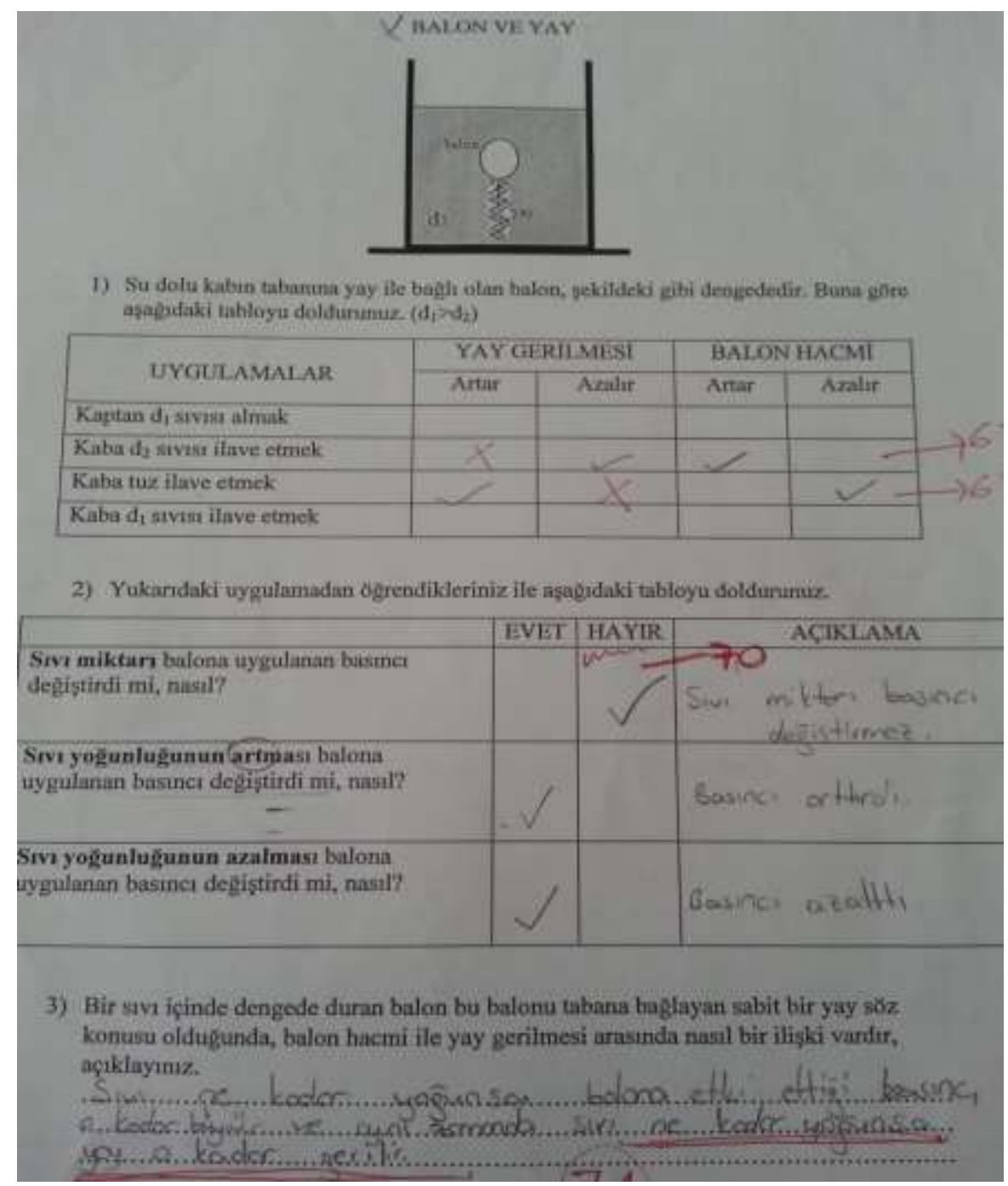

Şekil 11.On birinci çalışma yaprağına örnek

Araştırmanın on ikinci çalışma yaprağ "Basınç ve Biz" başlıklı bir materyaldir (Şekil 12). Bu çalışma yaprağı ile fen ve teknoloji dersi sekizinci sınıf programındaki "Kuvvet ve Hareket" ünitesinin basınç ile ilgili altıncı ve yedinci kazanımları hakkında öğrencilerdeki kavram yanılgıları tespit edilmeye çalışılmıştır. Burada tespit edilen kavram yanılgıları aşağıda verilmiştir;

67. $K Y=$ Bışaklarm ă̆ı̨larmm keskinleştirilmesi, katı basmon azaltmak içindir (6).

68. $K Y=$ Bardaktaki meyve suyunu pipetle içmek, siv basinc ile ilgilidir (14).

69. $K Y=$ Kişı kar ayakkabular, katı basincm artturmak için giyilir (2).

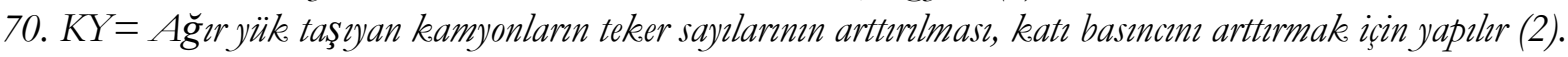

71. $K Y=$ Yatalak, hastalarn su yatağ 
Yerer, H., \& Öner Armağan, F. (2015). Kuvvet ve Hareket ünitesindeki kavram yanılgılarının çalışma yaprakları ile belirlenmesi. International Journal of Human Sciences, 12(2), 858-880. doi:10.14687/ijhs.v12i2.3391

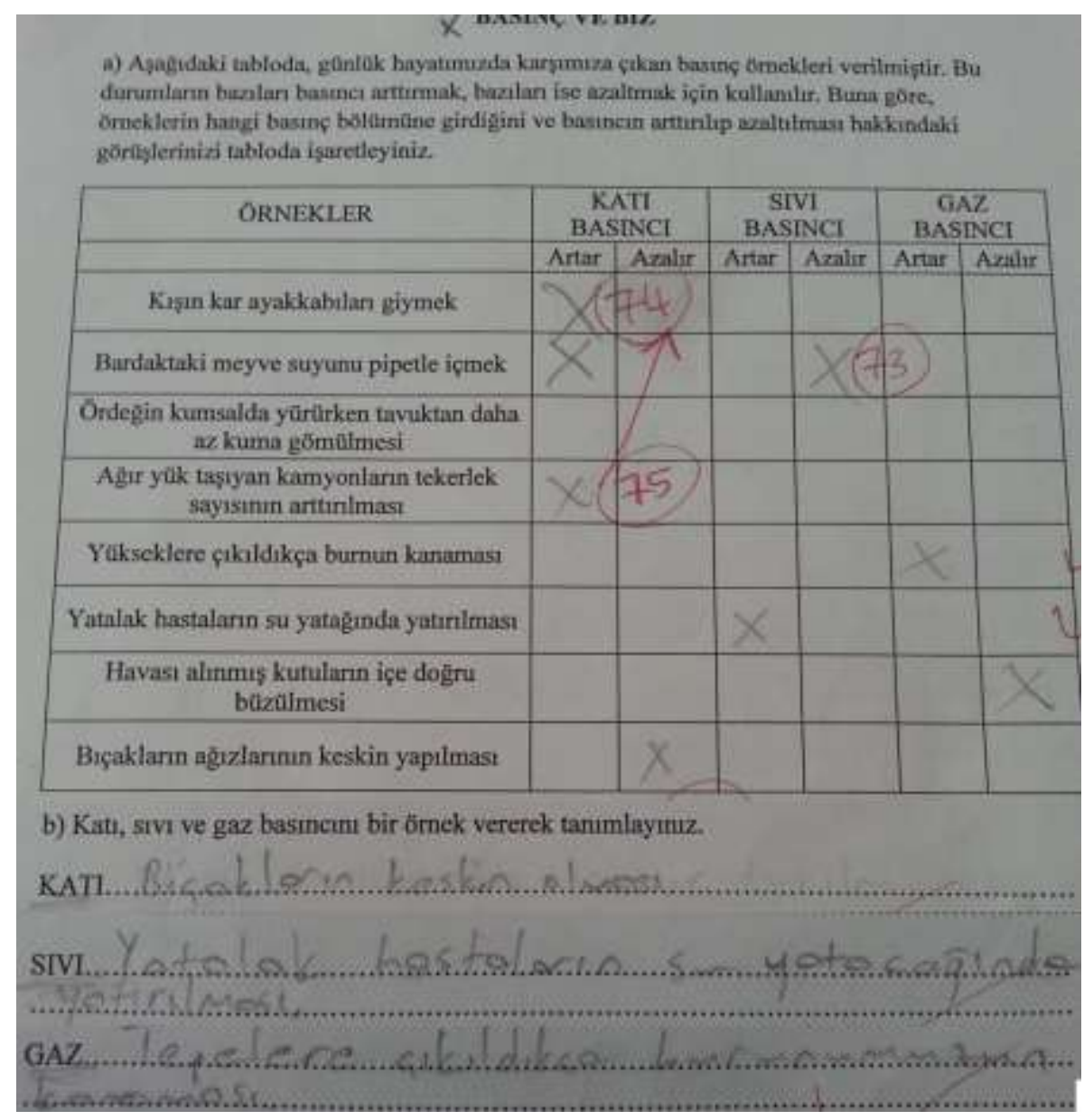

Şekil 12. On ikinci çalışma yaprağına örnek

\section{Sonuç ve Tartışma}

Yapılan çalışma sonunda elde edilen sonuçlar şu şekilde sıralanabilir;

Çalışmanın birinci çalışma yaprağ $\breve{g}_{1}$ bulgularına göre öğrenciler, aynı durumdaki cisme uygulanan kaldırma kuvvetinin sıvı miktarı değiştikçe değişeceğini düşünmektedirler. Bu bulgu Şahin'in (2010) çalışmasında tespit ettiği "sıvı miktarı kaldırma kuvvetini etkiler" kavram yanılgısı ile örtüşmektedir. Öğrencilerin bu şekilde düşünmeleri kaldırma kuvveti konusunu tam olarak anlayamamalarından kaynaklanabilir. Ünal \& Coştu'nun (2005) çalışmasında rastladığı "Sıvı miktarı arttığında, cismin batan kısmı da artar" ve "Sıvı miktarı arttığında, cismin batan kısmı azalır" yanılgıları da, bu çalışmanın bulguları ile paralellik göstermektedir.

İkinci çalışma yaprağında tespit edilen kavram yanılgısı, sadece bir kişide görülmüştür (7.KY). Sınıfin büyük çoğunluğu çalışma yaprağını doğru cevaplamıştır. Bu sonuç, bu çalışma yaprağının ilgili olduğu ve çalışma yapraklarının kazanımlara göre dağılımı tablosunda (tablo 1) verilen 1.4., 1.5. ve 1.8. kazanımlarının öğrencilerin biri hariç tümü tarafından doğru bir şekilde öğrenildiğini göstermektedir.

Üçüncü çalışma yaprağının uygulanması sonucu öğrencilerin birçoğunun sıv1 ve gazların kaldırma kuvveti ile ilgili kavram yanılgısına sahip olduğu tespit edilmiştir. Öğrenciler taşan sıvıların hacmi ile kaldırma kuvveti arasındaki ilişki konusunda; tüm cisimlerin batan kısımlarının hacimleri kadar hacimde sıvı taşırdıklarını; sadece yüzen ve askıda kalanların ağıllıkları kadar 
Yerer, H., \& Öner Armağan, F. (2015). Kuvvet ve Hareket ünitesindeki kavram yanılgılarının çalışma yaprakları ile belirlenmesi. International Journal of Human Sciences, 12(2), 858-880. doi:10.14687/ijhs.v12i2.3391

kaldırma kuvvetine uğradıklarını; batanların ise ağırlıklarından daha küçük değerde kaldırma kuvvetine uğradıklarını bilmemektedir. Bu durum Ünal \& Coştu'nun (2005) çalışmalarında rastladıklarn "Batan cisimlere uygulanan kaldırma kuvveti, yüzen ya da askıda kalanlara göre daha fazladır." kavram yanılgısı ve "Askıda kalan cisimlerin yoğunluğ $u$, swmmn yoğunluğundan kü̧̈üktür." kavram yanılgısı ile örtüşmektedir. Ayrıca öğrencilerin, cisimlerin batan kısımlarının hacimleri ile taşırdıkları sıvı miktarı arasında ilişki kuramamasına Şahin’in (2010) çalışmasında da rastlanmıştır.

Dördüncü çalışma yaprağında yoğunlukları belli cisimlerin yoğunluğu belli bir sıvı içinde hangi konumda kalacağ 1 çizilememiştir (17.KY). Bu durum göstermektedir ki, öğrenciler yoğunluk hesaplamayı bilseler bile, yüzme, batma ve askıda kalma durumlarını genelleyememekte ve cisimlerin sıvı içindeki konumlarını ifade edememektedir. Alan yazın araştırmalarında da benzer sonuçlara rastlanmaktadır. Yelgün'ün (2009) çalışmasında rastlanan;

\section{Öz kütleleri aym olan cisimlerden büyü̈k olanı suv içerisinde daha aşă̆ıda asılı kalır veya batar; \\ Ayn swo içinde asıl duran cisimlerden yüksekte durann öz, kütlesi derinde olandan fazladir / farklider;}

\section{Cisimler kendilerinden büyük öz kütleli sunlarda batar;}

gibi kavram yanılgıları, yine, batma, yüzme ve askıda kalma kanunlarının öğrenciler tarafından genellenemediğinin bir kanıtıdır. Ayrıca Ünal \& Coştu'nun (2005) çalışmaları da yine bu duruma paralellik göstermektedir. Ünal \& Coştu'nun (2005) çalışmalarından bu yanılgılara verilecek birkaç örnek şöyledir; "Yüzen cisimler batan ya da askıda kalan cisimlerden daha yoğundur; Askıda kalan cisimlerin yoğunluğu sıvının yoğunluğundan azdır; Askıda kalan cismin yoğunluğu yüzene / batana eşittir" gibi.

Beşinci çalışma yaprağında sıvı yoğunluğunun kaldırma kuvveti ile ilişkisinin yanı sıra, cismin sıvı içindeki konumu konusunda da kavram yanılgıları mevcuttur (21. KY-22. KY). Bu yanılgılar, Yelgün'ün (2009) çalışmasında bulduğu "Cisimler kendilerinden farklı öz kütleli sıvılarda askıda kalabilirler.” kavram yanılgısı ile örtüşmektedir. Yine aynı çalışma yaprağında kaldırma kuvvetinin sıvı yoğunluğu haricinde sıv1 miktarı/hacmi ile ilişkisi de araştırılmıştır. Buradan alınan sonuca göre öğrencilerde, sıvı kabını genişletmek/daraltmak veya sıvı miktarını arttırmak/azaltmak, cismin batan hacmini değiştirir yanılg1sı mevcuttur (19. KY-20.KY). Ünal \& Coştu'nun (2005) çalışmasında da, bu yanılgılara rastlamıştır;

Sivn miktar arttı̆gnda, cismin batan kısm da artar/azahr;

Sivn miktarn az̧aldığında, yüzen cisim batar;

Bir cisim az miktardaki sivnda fąla batar, çok miktardaki sunda az batar;

Cismin sivn içindeki durumunu sivmm hacmi belirler gibi.

Altıncı çalışma yaprağının sonuçlarına göre denge durumundaki cisimlere uygulanan kaldırma kuvvetinin, cismin ağırlı̆̆ına eşit olduğu gerçeği, çalışma grubunun büyük bir bölümünce bilinmemektedir. Görülen kavram yanılgılarından bazıları, alan yazında rastlanan "Asılı cisimlerin sıvıda bulundukları derinlik değiştikçe sıvının uyguladığı kaldırma kuvveti de değişir. Sıvı içinde asılı olan cisimlerden yüksekte olanına sıvı daha çok kaldırma kuvveti 
Yerer, H., \& Öner Armağan, F. (2015). Kuvvet ve Hareket ünitesindeki kavram yanılgılarının çalışma yaprakları ile belirlenmesi. International Journal of Human Sciences, 12(2), 858-880. doi:10.14687/ijhs.v12i2.3391

uyguluyor demektir" (Ünal \& Coştu, 2005; Yelgün, 2009) kavram yanilgısına benzemektedir (26.KY - 39.KY). Diğer yandan, Yelgün'ün (2009) çalışmasında rastlanan kavram yanılgıları olan;

Öz kütleleri aym olan cisimlerden büyü̈ olanı sivn içerisinde daha aşağıda asılı kalır veya batar;

Cisimler kendilerinden büyüle öz. kütleli swnlarda batar;

yanılgıları da bu araştırmada 32.KY olarak kodlanan kavram yanılgısı ile örtüşmektedir.

Yedinci çalışma yaprağından elde edilen 40. KY'na göre öğrenciler yer değiştiren sıvı ile batan cismin hacmi arasındaki ilişkiyi algılayamamaktadırlar. Aynı yanılgıya Besson'un (2004) çalışmasında da rastlanmıştır. Ayrıca 44.KY'na dayanarak bu cevabı veren öğrencinin yüzen, askıda kalan ya da batan cisimlerin tek ortak noktasının, batan hacimleri kadar sıvının yerini değiştirmesi olduğunu kavrayamadığ 1 tespit edilmiştir. Bu çalışma yaprağında karşılaşılan kavram yanılgıları, sayı olarak az olmasına rağmen kaldırma kuvvetinin hesaplanması konusundaki mantığın tam anlamılla kurulamadığını göstermektedir. Bu durum kütle-hacim-yoğunluk kavramlarının doğru anlamları ile kullanılmadığının kanıtı sayılabilir (41.KY - 42.KY - 43.KY). Strauss, Globerson, \& Mintz’in (1983) çalışma grubundaki üstün yetenekli çocukların dışındaki öğrenciler de kütle-hacim ve yoğunluk kavramları arasında ilişki kuramamaktadırlar.

Sekizinci çalışma yaprăğında tespit edilen kavram yanılgıları çalışma grubunun büyük kısmında tespit edilmiştir. Bu kavram yanılgılarından biri şu şekildedir; Gazla dolu bir kaba bırakılan içi gazla doldurulmuş balonun hacmi ne kadar fazla olursa, balona uygulanan kaldırma kuvveti de artar. Bu durumda balon yukar1 yönde hareket eder (48.KY - 49.KY). Ortaya çıkan kavram yanılgılarına bakıldığında öğrenciler, gazın, boyut olarak küçülen balona daha fazla kaldırma kuvveti uygulayacağını ve balonun da buna göre hareket edeceğini düşünmektedirler. Oysa hacmi artan balona uygulanan kaldırma kuvveti daha fazla olacaktır. Balon küçüldükçe daha yoğun hale gelecek ve aşağ 1 yönde ilerleyecektir. Diğer yandan, kabın içindeki gaz yoğunlaştırıldıkça, balona uygulanan kaldırma kuvveti de artar ve cisim yukarı yönde hareket eder (47.KY - 48.KY). Bu durum siviların kaldırma kuvvetine benzetilebilir. Nasıl ki sıv1 yoğunluğu kaldırma kuvveti ile doğru orantılı ise kabın içindeki gaz yoğunluğu arttıkça, kaldırma kuvveti de artacaktır.

Dokuzuncu çalışma yaprağında tespit edilen sıvı basıncı hakkındaki kavram yanılgısı (57.KY), Besson \& Viennot'un (2004) çalışmalarında tespit ettikleri “sıvı basıncı sıvının toplam hacmi ile ilişkilidir” yanılgısı ile benzerlik göstermektedir.

Onuncu çalışma yaprağı sonucuna göre sıvı basıncının kesit alanına uzaklığı (yani yükseklik) ve sıvının öz kütlesi, sıvı basıncına etki eden etmenlerdir. İki değer de sıvı basıncı ile doğru orantılıdır. Bu bilgiler kullanılarak cevap verilmesi gereken boşluk doldurmalı sorulardan alınan sonuçlarda, bazı kavram yanılgılarına ulaşılmıştır (58.KY - 59.KY - 60.KY - 61.KY). Ulaşılan kavram yanılgıları bir önceki çalışma yaprağında çıkan yanılgılara benzer özellikler taşımaktadır. Bu yanılgılara ek olarak Önen'in (2005) ve Şahin'in (2010) araştırmaları sonucunda tespit ettikleri "Sıvı basıncı kap şekline göre değişir." yanılgısına da yine, bu çalışmada rastlanmaktadır (58.KY).

On birinci çalışma yaprağında öğrencilerin büyük bir kısmında basınç konusunda kavram yanılgısına sahip olduğu tespit edilmiştir. Bir sıvı içinde tabana sabit bir yay ile bağlanan bir balon, sıvının en üst seviyesine kadarki sıvı miktarının uyguladığı basınç nedeniyle, ya aşağı yönde ya da yukarı yönde hareket eder. Sıvı miktarı arttıkça, balona uygulanan basınç artar, balonun hacmi 

belirlenmesi. International Journal of Human Sciences, 12(2), 858-880. doi:10.14687/ijhs.v12i2.3391

küçülür, balon aşağı yönde hareket eder ve yay gerilmesi azalır. Aynı şekilde, sıvı miktarı azaldıkça balona uygulanan basınç azalır, balonun hacmi artar, balon yukarı yönde hareket eder ve yay gerilmesi artar. Ancak grubun büyük bölümünde bu durum tam tersi olarak bilinmektedir. Çünkü "Balon ve Yay" başlıklı çalışma yaprağından çıkan kavram yanılgılarından 65. ve 66. olarak kodlananlar, grubun büyük çoğunluğunda görülmektedir. Ayrıca üç öğrenci, sıv1 miktarının sıvı basıncını etkilemeyeceğini belirtmiştir (68.KY). Diğer yandan sıv1 yoğunluğunun sıvı basıncinı değiştirmeyeceğini veya sıvı basınc1 ile ters orantılı olduğunu düşünen öğrenciler de vardır (67.KY - 69.KY).

On ikinci çalışma yaprağında katıların uyguladığı basıncın temas alanları ile ters orantılı olduğunu bilmeyen öğrenciler, 67., 69. ve 70. kavram yanılgilarına sahiptirler. Bu yanılgıya, Akdemir'in (2005) ve Bozan \& Küçüközer’in (2007) çalışmalarında da rastlanmıştır; "Katı basıncı sadece temas alanı ile ilişkilidir ve doğru orantılıdır.” Dĭ̆er yandan sıvı basıncının kullanıldığı su yatakları hakkındaki yanılgı da sıvı basıncının gaz basıncı ile ilişkilendirilmiş olmasıdır (71.KY). Ayrıca bardaktaki meyve suyunu pipetle içmek, sıvı basıncından ziyade, gaz basıncı ile ilgilidir. Atmosferin yani açık havanın basınç uygulaması nedeniyle, bardaktaki sıvı, yukarı yönde hareket etmektedir (68.KY).

\section{5.Öneriler}

\subsection{Uygulayıcılara Yönelik Öneriler}

1. Bu çalışmada tespit edilen kavram yanılgıları öğretmenler tarafindan derslerde daha fazla dikkate alınabilir.

2. Sarmal yapıda ilerleyen "Kuvvet ve Hareket" ünitesinin derse giriş aşamasında önceki y1llara ait olan kazanımlan üzerinde durulabilir.

\subsection{Araştırmacılara Yönelik Öneriler}

1. Bu çalışmada 8. sınıf kuvvet ve hareket ünitesinindeki kavram yanılgılarının çalışma yaprakları ile belirlenmesi araştırılmıştır. Bu araştırmada tespit edilen kavram yanılgılarının giderilmesine yönelik başka çalışmalar yapılabilir.

2. 8. sınıf kuvvet ve hareket ünitesinindeki kavram yanılgılarının belirlenmesine yönelik olarak kullanılan çalışma yapraklarına ek olarak farklı rehber materyaller geliştirilebilir.

3. 8. sinıf kuvvet ve hareket ünitesinindeki kavram yanılgilarının belirlenmesine yönelik olarak kullanılan çalışma yapraklarına ek olarak alternatif öğretim yöntemleriyle desteklenen farklı çalışmalar yapılabilir. Örneğin soyut kavramların görselleştirilmesi adına, animasyon, simülasyon vb. bilgisayar destekli tekniklerden yararlanılabilir.

\section{Kaynaklar}

Akdemir, E. (2005). Ilkë̈gretim ikinci kademe yedinci simf öğrencilerinin katı ve suvlarn basinc konusunda sahip olduklar kavram yamlgzlar. Balıkesir Üniversitesi Fen Bilimleri Enstitüsü. Yayınlanmamış Yüksek Lisans Tezi, Balıkesir.

Atasoy Ş. \& Akdeniz A. R. (2006). Yapılandırmacı öğrenme kuramına uygun geliştirilen çalışma yapraklarının uygulama sürecinin değerlendirilmesi. Milli Ĕ̈̆itim Dergisi, 170, 157-175. 
Yerer, H., \& Öner Armağan, F. (2015). Kuvvet ve Hareket ünitesindeki kavram yanılgılarının çalışma yaprakları ile belirlenmesi. International Journal of Human Sciences, 12(2), 858-880. doi:10.14687/ijhs.v12i2.3391

Atasoy, Ş. (2008). Öğretmen adaylarmm newton'un bareket kanunlar konusundaki kavram yamlgzlarmm giderilmesine yönelik geliştirilen çalısma yapraklarmmn etkililiğinin araştırlması. Yayınlanmamış Doktora Tezi. Karadeniz Teknik Üniversitesi Fen Bilimleri Enstitüsü, Trabzon.

Beeth, M. E. (1998). Teaching for conceptual change: Using status as a metacognitive tool. Science Education, 82(3), 343-356

Besson, U. (2004). Some features of causal reasoning: common sense and physic teaching. Research in Science \& Technological Education, 22 (1), 113-125.

Besson, U. \& Viennot, L. (2004). Using models at the mesoscopic scale in teaching physics: two experimental interventions in solid friction and fluid statics. International Journals of Science Education, 26 (9), 1083- 1110.

Bozan, M. \& Küçüközer, H. (2007). Elemantary school students’ errors in solving problems releated to pressure subjects. Elementary Education Online, 6 (1), 24-34.

Chong, V. D., Salleh, S. M., \& AiCheong, I. P. (2013). Using an activity worksheet to remediate students' alternative conceptions of metallic bonding. American International Journal of Contemporary Research, 3(11), 39-52.

Clement, J., Brown, D.E., \& Zietsman, A. (1989). Not all preconceptions are misconceptions: finding 'anchoring conceptions' for grounding instruction on students' intuitions. International Journal of Science Education, 11, 554- 565

Demirel, Ö. (2001). Öğretim teknolojileri ve materyal geliştirme. Ankara: Pegem A Yayıncıllk.

Dykstra, D. (1986). Science Education in Elementary School: Some Observations. Journal of Research in Science Teaching, 23(9), 853-856

EARGED. (2003). Üçüncü uluslararası matematik ve fen bilgisi çalışması (TIMSS, 1999), Ulusal Rapor. Ankara: MEB- Eğitimi Araştırma ve Geliştirme Dairesi Başkanlığ

Engel Clough, E., \& Driver, R. (1986). A Study of consistency in the use of students' conceptual frameworks across different task contexts. Science Education, 70(4), 473- 496.

Gil-Perez, D., \& Carrascosa, J. (1990). What to do about science 'misconceptions', Science Education,74(5), 531-540.

Hewson P. W., \& Hewson, M. G., (1988). An appropriate conception of teaching science: a view from studies of science learning. Science Education, 72(5), 597-614.

Karasar, N. (2005). Bilimsel araştırma yöntemi. Ankara: Nobel Yayın Dağıtım.

Miles, M.B., \& Huberman, A.M. (1994). Qualitative Data Analysis: An Expanded Sourcebook (2nd ed.). Thousand Oaks, California: SAGE.

Novak, J.D. (2002). Meaningful learning: the essential factor for conceptual change in limited or inapproprite propositional hierarchies leading to empowerment of learners, Science Education, 86, 548-571.

Önen, F. (2005). Illkëğretimde basinç konusunda ögrencilerin sahip oldü̆u kavram yamlgzlarmmn yapılandırmac yaklaşım ile giderilmesi. Yayınlanmamış Yüksek Lisans Tezi. Marmara Üniversitesi Eğitim Bilimleri Enstitüsü, İstanbul.

Palmer, D. (1999). Exploring the link between students' scientific and nonscientific conceptions. Science Education, 83(4), 639-653.

Pines, A., \& West, L. (1986). Conceptual understanding and science learning: an interpretation of research within sources of knowledge framework. Science Education, 70(5), 583-604.

Pintrich, P.R., Marx, R.W., \& Boyle, R.B. (1993). Beyond cold conceptual change: the role of motivational beliefs and classroom contextual factors in the process of conceptual change. Review of Educational Research, 63(2):167-199

Smith, J.P., Disessa, A. A., \& Roschelle, J. (1993). Misconceptions reconceived: A constructivist analysis of knowledge of transition. The Journal of the Learning Sciences, 3(2), 115-163.

Strauss, S., Globerson, T., \& Mintz, R. (1983). The influence of training for the atomistic schema on the development of the density concept among gifted and nongifted children. Journal of Applied Developmental Psychology, 4, 125- 147. 
Yerer, H., \& Öner Armağan, F. (2015). Kuvvet ve Hareket ünitesindeki kavram yanılgılarının çalışma yaprakları ile belirlenmesi. International Journal of Human Sciences, 12(2), 858-880. doi:10.14687/ijhs.v12i2.3391

Şahin, C.. (2010). İlkë̈̆retim 8. sinf "Kuvvet ve Hareket” ünitesinde "Zenginleştirilmiş 5 e ögretim modeli”ne göre rehber materyaller tasarlanması, uygulanması ve değerlendirilmesi. Yayınlanmamış Doktora Tezi, Karadeniz Teknik Üniversitesi Fen Bilimleri Enstitüsü, Trabzon.

Şahin Ç, İpek Akbulut, H., \& Çepni S. (2012). Teaching of solid pressure with animation, analogy and worksheet to primary 8th students. The Journal of Instructional Technologies \&Teacher Education 1(1), 22-51.

Ünal, S., \& Coştu, B. (2005). Problematic issue for students: Does it sink or float. Asia-Pasific Forum on Science Learning and Teaching, 6(1), 1-16..

Yelgün, A. (2009). İlköğretim 8. sinnf ögrencilerinin suvılarn kaldırma kuvveti ile ilgili kavram yanılgılar ve oluşum sebepleri. Yayınlanmamış Yüksek Lisans Tezi. Atatürk Üniversitesi Fen Bilimleri Enstitüsü, Erzurum.

\section{Extended English Abstract}

Scientific phenomena play a major role in our lives. Understanding science is only possible with a correct science education. Due to the fact that science was delivered through traditional methods so far, the science success rate in our country was determined to be poor (Education Research and Development Association [EARGED], 2003). In line with the objection of remedying this issue, the curricula focus on alternative teaching approaches that help students with meaningful learning. Constructivist approach, which adopts the principle of learning by doing and experiencing something for students, is among these approaches.

In the constructivist approach, students construct knowledge individually rather than using the information as it is. Prior knowledge and personal characteristics of individuals as well as the learning environment are very important in respect to learning (Smith, Disessa, \& Roschelle, 1993). Prior knowledge of students is one of the factors that affect student learning in a positive or negative manner (Pines \& West 1986; Pintrich, Marx, \& Boyle, 1993). Therefore, it is particularly important to identify the prior knowledge of students (Beeth, 1998) and deliver an education accordingly (Engel Clough, \& Driver, 1986; Hewson \& Hewson, 1988). Because, students interpret the new information with their existing ideas and beliefs while they are learning science; and the new information is either changed or reconstructed to this end (Palmer, 1999).

Concepts which are not constructed accurately in the mind cause misconceptions. Misconceptions are thoughts that are incompatible with information that is accepted as a scientific fact (Clement, Brown \& Zietsman, 1989). Misconceptions may stem from the insufficiency of methods and techniques. Several studies emphasize that traditional teaching methods may be incapable of correcting misconceptions (Dykstra, Boyle, \& Monarch, 1992; Pines \& West, 1986).

When used accurately, teaching methods and techniques positively affect the quality of education. In-depth determination of the existing misconceptions of students can prevent any future mistakes. It is very important to use worksheets that include open-end questions and exercises to this end. The easy use of worksheets as well as their advantage for preparation based on content, and the aspect of saving the lessons from being monotonous make worksheets one of the preferred alternative teaching methods of science education (Demirel, 2001)

The literature review has revealed that misconceptions were also determined through worksheets in the previous studies as well. Similarly, the results of this study also suggest that worksheets are effective in determining misconceptions (Atasoy \& Akdeniz, 2006; Chong, Salleh 
Yerer, H., \& Öner Armağan, F. (2015). Kuvvet ve Hareket ünitesindeki kavram yanılgılarının çalışma yaprakları ile belirlenmesi. International Journal of Human Sciences, 12(2), 858-880. doi:10.14687/ijhs.v12i2.3391

\& AiCheong, 2013; Coştu \& Ünal, 2005; Şahin, İpek Akbulut \& Çepni, 2012). Therefore, this study aimed for preparing and delivering worksheets for 8th grade Force and Motion unit.

"Force and Motion" unit is one of the spirally progressing subjects in the science curriculum (MNE, 2013). Therefore, this unit is one of the basic subjects of physics. Accepting a scientific phenomenon that we encounter in daily life as it is rather than understanding its underlying reasons weaken our questioning skills. For instance, we encounter concepts such as "buoyancy force", "pressure" and "density" all through our lives, yet we never feel the need to question these. This unit, which explains concepts such a "buoyancy force", "floatation", "sinking" and pressure" with their reasons, could be explained more easily and fluently with worksheets based on constructivist approach. Furthermore, existing misconceptions could be determined based on the responses given to worksheets.

Survey method, which is a qualitative research method, has been employed in this research. The study group was determined as 8th grade students attending to a secondary school with a good socioeconomic level situated in Kayseri province, Turkey. 25 8th grade students participated in the study. These students were selected through sampling as appropriate. The age group of these students is $14-15$ years. The group consists of 15 female and 10 male students.

The subjects on unit outcomes within the central exams preparation test books of last five years as well as course books of Ministry of National Education were examined during the preparation of these worksheets. Furthermore, relevant studies in the literature were reviewed as well in order to address the subjects that prove to be difficult for students. Then, two science teachers and one science educator examined these worksheets; and required spiral modifications were made accordingly. The worksheets were delivered for 3 weeks as the specified period in the curriculum.

Content analysis technique was used for data analysis. As a result of the study, the misconceptions of students regarding the concepts in Force and Motion unit were determined. "The quantity of liquid affects ascending force," "the ascending force affecting a floating object is greater than that object's weight" and similar misconceptions could be given as examples to the misconceptions included in study findings. It is believed that this study will be a useful guide for teachers and researchers who aim for determining the misconceptions in force and motion subjects with a constructivist approach. 